\title{
Why sauropods had long necks; and why giraffes have short necks
}

The necks of the sauropod dinosaurs reached $15 \mathrm{~m}$ in length: six times longer than that of the world record giraffe and five times longer than those of all other terrestrial animals. Several anatomical features enabled this extreme elongation, including: absolutely large body size and quadrupedal stance providing a stable platform for a long neck; a small, light head that did not orally process food; cervical vertebrae that were both numerous and individually elongate; an efficient air-sac-based respiratory system; and distinctive cervical architecture. Relevant features of sauropod cervical vertebrae include: pneumatic chambers that enabled the bone to be positioned in a mechanically efficient way within the envelope; and muscular attachments of varying importance to the neural spines, epipophyses and cervical ribs. Other long-necked tetrapods lacked important features of sauropods, preventing the evolution of longer necks: for example, giraffes have relatively small torsos and large, heavy heads, share the usual mammalian constraint of only seven cervical vertebrae, and lack an air-sac system and pneumatic bones. Among non-sauropods, their saurischian relatives the theropod dinosaurs seem to have been best placed to evolve long necks, and indeed their necks probably surpassed those of giraffes. But 150 million years of evolution did not suffice for them to exceed a relatively modest $2.5 \mathrm{~m}$. 
Michael P. Taylor, Department of Earth Sciences, University of Bristol, Bristol, England.

Mathew J. Wedel, College of Osteopathic Medicine of the Pacific and College of Podiatric Medicine, Western University of Health Sciences, Pomona, California, USA.

Corresponding author: Michael P. Taylor, c/o Oakleigh Farm House, Crooked End, Ruardean, Gloucestershire GL17 9XF, England. Tel. +44 1594546 941. Email dino@miketaylor.org.uk 


\section{INTRODUCTION}

Neck elongation occurs in many extant clades and is also found in many extinct groups. Some modern birds and certain extinct tetrapods have necks that are relatively long (i.e. as a proportion of total body length). Although these are interesting modifications of the basic tetrapod body plan, here we are concerned with absolute neck length. This is of interest because of the great mechanical difficulties imposed by absolutely long necks, and the anatomical novelties that needed to evolve to make such necks possible.

The necks of the sauropod dinosaurs were by far the longest of any animal, six times longer than that of the world record giraffe and five times longer than those of all other terrestrial animals. In many long-necked animals, the legs are of a similar length and so the neck elongation can be explained as a simple consequence of the need to reach down to ground level - for example in order to drink. By contrast, the necks of all sauropods were longer than necessary to reach the ground - in most cases, many times longer.

We survey the evolutionary history of long necks in sauropods and other animals, and consider the factors that allowed sauropod necks to grow so long. We then examine the osteology of sauropod necks more closely, comparing their cervical anatomy with that of their nearest extant relatives, the birds and crocodilians, and discussing unusual features of sauropods' cervical vertebrae. Finally we discuss which neck elongation features were absent in non-sauropods, and show why giraffes have such short necks.

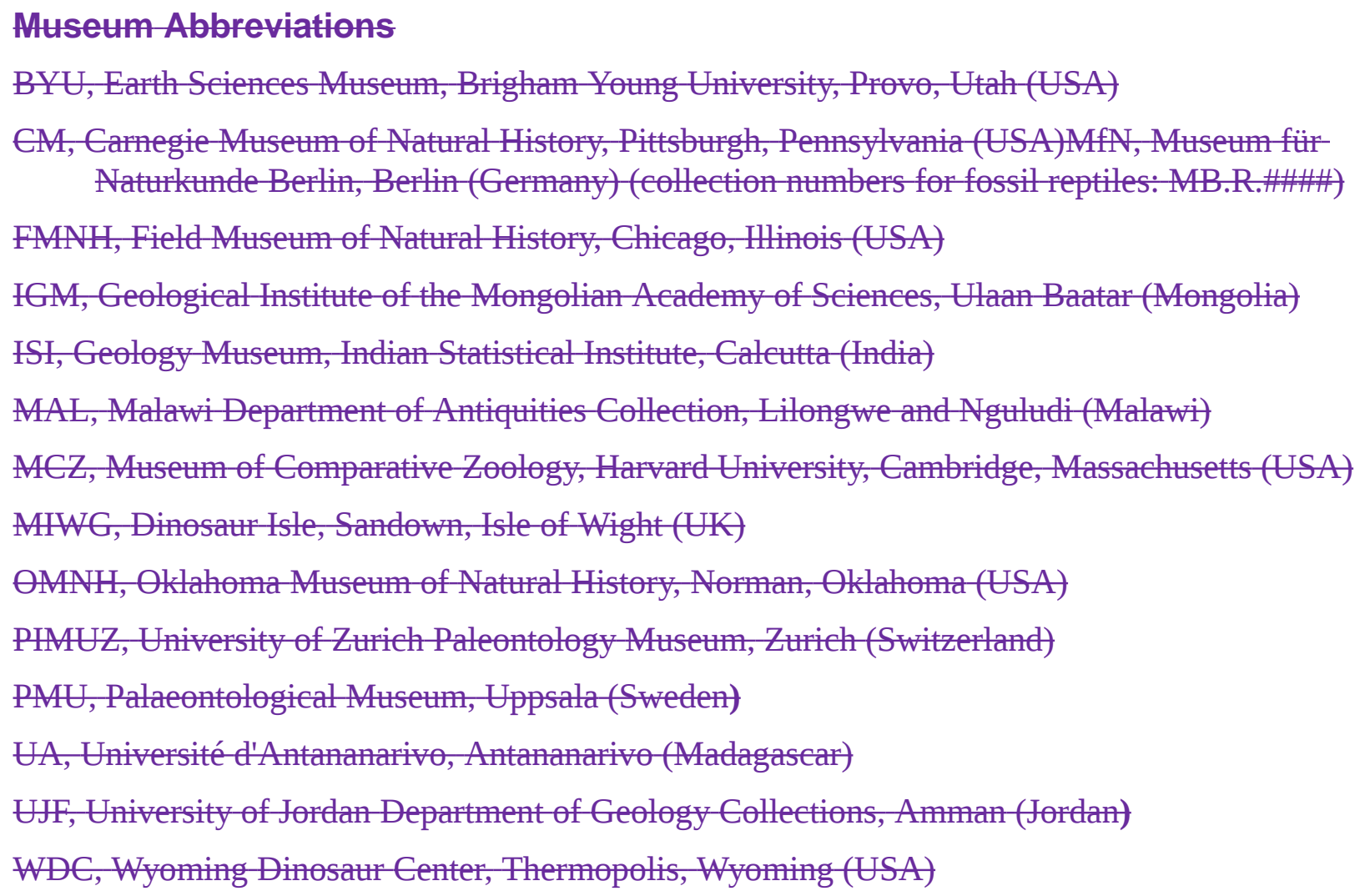




\section{ZMNH, Zhejiang Museum of Natural History, Hangzhou (China)}

\section{LONG NECKS IN DIFFERENT TAXA}

While they reach their zenith in sauropods, long necks have evolved repeatedly in several different groups of tetrapods. Long necks impose a high structural and metabolic cost, but provide evolutionary advantages including an increased browsing range (Cameron and du Toit 2007) and the ability to graze a wide area without locomotion (Martin 1987) and probably played some role in mate attraction (Simmons and Scheepers 1996; Senter 2006; Taylor et al. 2011). Here we survey the longest necked taxa in several groups of extant and extinct animals (Figs. 1, 2).

Note that most of the length estimates in this section are necessarily imprecise, being based on incomplete specimens and cross-scaling assumptions. They be taken only as indicative, not as reliable figures.

\section{Extant Animals}

Among extant animals, adult bull giraffes can attain a neck of $2.4 \mathrm{~m}$ (Toon and Toon 2003, p. 399), and no other extant animal exceeds half of this. The typical length of the neck of the ostrich is only $1.0 \mathrm{~m}$ (sum of vertebral lengths in Dzemski and Christian 2007, table 1, plus 8\% to allow for intervertebral cartilage - see Cobley 2011, p. 16).

\section{Extinct Mammals}

The largest terrestrial mammal of all time was the long-necked rhinoceratoid Paraceratherium Forster-Cooper 1911 (= Baluchitherium Forster-Cooper 1913, Indricotherium Borissiak 1915). The length of its neck can be measured as $1.95 \mathrm{~m}$ from the skeletal reconstruction of Granger and Gregory (1936, figure 47), modified here as Fig. 2.1. This length, however, is rather shorter than suggested by the text (pp. 10-20), in which lengths of 39, 39, 36, 29.6 and $18 \mathrm{~cm}$ are given for cervicals 1, 2, 4, 6 and 7, even though C2 and C7 are reported as of "size class III". When the lengths of C2 and C7 are multiplied by 1.3 to give lengths of equivalent "size class I" bones (Granger and Gregory 1936, p. 65), their lengths become 50.7 and $23.4 \mathrm{~cm}$. The total length of the preserved cervicals would then be $178.7 \mathrm{~cm}$ even though C3 and C5, which were not recovered, are omitted. If these vertebrae are tentatively assigned lengths intermediate between those that preceded and succeeded them (i.e., 43.4 and $32.8 \mathrm{~cm}$ ) then the total length of all seven centra is $254.9 \mathrm{~cm}$, more than 30\% longer than the illustrated length. At any rate, the material available suggests a total neck length in the $2-2.5 \mathrm{~m}$ range.

\section{Theropods}

In each of the successively more derived clades Ornithodira, Dinosauria, and Saurischia, the primitive state was an increasingly long neck (Gauthier 1986, Sereno 1991a, Langer 2004). Within Saurischia, both branches of that clade, Sauropodomorpha and Theropoda, further elongated their necks (Galton and Upchurch 2004). So sauropods inherited as their primitive state necks that were already more elongated, and heads that were proportionally smaller, than in most animals. 
Within Theropoda, at least three lineages evolved especially long necks. The lengths of their necks can be estimated from their incomplete remains, though with some uncertainty, as follows.

Therizinosaurus cheloniformis Maleev 1954 is a bizarre, long-necked giant theropod, known from incomplete remains. Measuring from Barsbold (1976, figure 1), its humerus was about 75 cm long. In a skeletal reconstruction of the therizinosauroid Nanshiungosaurus Dong 1979 by Paul (1997, p. 145), modified and rescaled here as Fig. 2.2, the neck is 2.9 times the length of the humerus. If Therizinosaurus were similarly proportioned, its neck would have been about $2.2 \mathrm{~m}$ long.

Another giant theropod, Gigantoraptor erlianensis Xu et al. 2007 belongs to another long-necked group, Oviraptorosauria. Measured from the skeletal reconstruction of Xu et al. (2007, figure 1A), modified here as Fig. 2.4, it appears to have had a neck $2.15 \mathrm{~m}$ in length although this is conjectural as almost no cervical material is known.

\section{Pterosaurs}

Although it is often noted in general terms that azhdarchid pterosaurs had long necks (e.g., Howse 1986; Witton and Naish 2008), there are no published numeric estimates of neck length in this group. This is due to the lack of any published azhdarchid specimen with a complete neck (Witton and Habib 2010): Quetzalcoatlus specimens at the Texas Memorial Museum may have complete necks, but have been embargoed since the early 1980s (Langston 1981): a monographic description is still awaited. In the absence of a complete neck, all length estimates are uncertain, but it is nevertheless possible to arrive at an approximate length.

The azhdarchid for which the most complete neck has been described is Zhejiangopterus linhaiensis Cai and Wei 1994, so we will base our estimates on this species. Cai and Wei (1994, table 7) give the lengths of cervicals 3-7 for three specimens, ZMNH M1323, M1324 and M1328. In all three, C5 is the longest cervical, as is generally true of pterodacyloid pterosaurs including azhdarchids (Howse 1986, p. 323). Cai and Wei (1994) do not give lengths for C1 and $\mathrm{C} 2$, stating only that "the atlas-axis is completely fused and extremely short but morphological details are indistinct due to being obscured by the cranium” (p. 183, translation by Will Downs). Their figure 6, a reconstruction of Zhejiangopterus linhaiensis, bears this out, showing the atlas-axis as about one quarter the length of C3. Using this ratio to estimate the C1-2 lengths for each specimen, we find by adding the lengths of the individual cervicals that the three specimens had necks measuring approximately 511, 339 and $398 \mathrm{~mm}$. These lengths are 3.60, 4.04 and 4.06 times the lengths of their respective C5s. On average, then, total C1-C7 neck length in known Zhejiangopterus specimens was about 3.85 times that of C5.

The azhdarchid Arambourgiania philadelphiae (Arambourg 1959) is the largest pterosaur for which cervical material has been described. Its type specimen, UJF VF1, is a single cervical vertebra. It was nearly complete when found, but has since been damaged and is now missing its central portion, but plaster replicas made before the damage indicate the extent of the missing portion. The preserved part of the vertebra was $620 \mathrm{~mm}$ long before the damage, and when complete it would have been about $780 \mathrm{~mm}$ long (Martill et al. 1998, p. 72). Assuming that the preserved element is C5, as considered likely by Howse (1986, p. 318) and Frey and Martill (1996, p. 240), the length of the C1-C7 region of the neck can be estimated as 3.85 times that 
length, which is $3.0 \mathrm{~m}$.

The total number of cervical vertebrae in Zhejiangopterus is not clear: Cai and Wei (1994) imply that there are seven, and their illustrations (figures 5, 6) indicate that in at least one specimen the vertebral column is complete. However, at least some azhdarchids seem to have have nine cervical vertebrae (e.g., Phosphatodraco, Pereda Suberbiola et al. 2003), although the ninth "cervical” bears a long vertically oriented rib and must have contributed to the length of the torso rather than the neck. Bearing this in mind, the total neck length of Arambourgiania may have somewhat exceeded $3.0 \mathrm{~m}$. In azhdarchids, C8 may be between $20 \%$ and $50 \%$ the length of C5 (Pereda Suberbiola et al. 2003, p. 86), which might amount to 16-39 cm in Arambourgiania.

Another azhdarchid, Hatzegopteryx thambema Buffetaut et al. 2002a, may have been even larger than Arambourgiania, but no cervical material is known. Since its skull was much more robust that those of other azhdarchids (Buffetaut et al. 2002a, p. 183), it was probably carried on a proportionally shorter and stronger neck.

\section{Plesiosaurs}

As marine reptiles, plesiosaurs benefited from the support of water and so lived under a wholly different biomechanical regime than terrestrial animals. The long necks of elasmosaurid plesiosaurs were constructed very differently from those of sauropods, consisting of many very short cervicals - 76 in the neck of Albertonectes vanderveldei Kubo et al. 2012 and 71 in Elasmosaurus platyurus Cope 1868 (Sachs 2005, p. 92). Despite their marine lifestyle and very numerous cervicals, elasmosaurids did not attain neck lengths even half those of the longest-necked sauropods. According to Kubo et al. (2012, p. 570), “The approximately $7 \mathrm{~m}$ long neck of Albertonectes is the longest known for elasmosaurs (equal to 62\% of total postcranial length)." Since the neck of Albertonectes was found articulated, the reported total neck length presumably includes the invertebral cartilage. Other elasmosaurs may have had equally long necks. The cervical vertebrae of Elasmosaurus platyurus holotype ANSP 10081 sum to 610.5 cm, based on individual vertebral lengths listed by Sachs (2005, p. 95). For other plesiosaurs, Evans (1993) estimated that the thickness of intercervical cartilage amounted to $14 \%$ of centrum length in Muraenosaurus Seeley 1874 and 20\% in Cryptoclidus Seeley 1892. Using the average of $17 \%$ for Elasmosaurus, we can estimate its total neck length as $7.1 \mathrm{~m}$ (Fig. 2.5). This is within $6 \%$ of Leidy's (1870) estimate of “almost twenty-two feet”, or about $6.7 \mathrm{~m}$, and approximately equal to the 7-m neck length reported for Albertonectes by Kubo et al. (2012).

These longest necks are in the Diplodocus class. They lack most of the characters that we later identify as contributing to neck length in sauropods, but solved the support issue by being marine. We know from whales (see below) that a $7 \mathrm{~m}$ trachea need not impose the difficulties we might expect; but we don't know whether sufficiently large lungs would fit inside an elasmosaur torso. So far, little work has been done on the physiological implications of neck elongation in plesiosaurs; more is needed.

\section{Tanystropheus}

The bizarre prolacertiform Tanystropheus merits mention as possessing perhaps the longest neck relative to torso length of any animal. The complete skeleton PIMUZ T 2818 has a total length of $420 \mathrm{~cm}$ (Nosotti 2007, p. 8), of which the neck accounts for $211.2 \mathrm{~cm}$ (Tschanz 1988, p. 
1003) - almost exactly half. Nosotti (2007, p. 8) estimates the total length of the incomplete specimen PIMUZ T 2793 as 535 cm. If it were similarly proportioned to PIMUZ T 2818, its neck would have measured $269 \mathrm{~cm}$.

Despite more than a century of study, there is no consensus on the habits or even environment of Tanystropheus. However, Nosotti (2007, p. 76) argues that limb proportions "unequivocally indicate the adaptation to an aquatic mode of life". If this is correct, then its neck was subject to a quite different biomechanical regime than those of sauropods.

\section{Sauropods}

The necks of sauropod dinosaurs greatly exceeded in length those of all other animals (Wedel 2006a). As noted above, they inherited long necks from their basal sauropodomorph ancestors. From this base, they elongated them yet further - both in ancestral forms and further still in more derived groups. Exceptionally long necks evolved in at least four distinct sauropod lineages (Fig. 3).

The basal eusauropod Mamenchisaurus Young 1954 is known from several species. One, $M$. hochuanensis Young and Zhao 1972, is known from an individual with a complete neck that is $9.5 \mathrm{~m}$ in length (personal measurement, MPT). Another species, M. sinocanadorum Russell and Zheng 1993 is known only from skull elements and anterior cervical vertebrae, but by comparing this material with the corresponding elements of $M$. hochuanensis, its neck can be estimated to have been about $12 \mathrm{~m}$ long.

The known material of the diplodocid Supersaurus Jensen 1985 includes a cervical vertebra whose centrum is $138 \mathrm{~cm}$ long. Comparing this with the lengths of similar vertebrae from the closely related Barosaurus Marsh 1890, for which much more complete necks are known, suggests a complete neck length in the region of 15 m (Wedel 2007a, p. 197).

The holotype and largest known specimen of Sauroposeidon Wedel et al. 2000a consists of a sequence of four articulated cervical vertebrae, the largest of which has a centrum $125 \mathrm{~cm}$ long. The complete cervical series of the morphologically similar and possibly closely related brachiosaurid Giraffatitan Paul 1988 is known, and consists of 13 cervicals measuring $8.5 \mathrm{~m}$. The Sauroposeidon cervicals are on average 37\% longer than the corresponding vertebrae of Giraffatitan, suggesting a complete neck length of about 11.5 m. If Sauroposeidon is a basal somphospondyl rather than a brachiosaurid, as suggested by D'Emic and Foreman (2012), then a more apposite comparison might be to Euhelopus, which had 17 cervicals. The complete cervical series of Euhelopus PMU R233 is 13.2 times the length of the longest cervical (3765 mm vs 285 mm; Wiman 1929). Applying a similar scaling relationship to Sauroposeidon, and conservatively assuming that the largest available vertebra was the longest in the neck, yields an estimated neck length of $16.5 \mathrm{~m}$. We will not know which of the two estimates is more accurate until more articulated cervical material of Sauroposeidon comes to light.

Puertasaurus Novas et al. 2005 is the largest titanosaur for which cervical material has been described. The single known cervical vertebra is $118 \mathrm{~cm}$ in total length, including overhanging prezygapophyses, and its incomplete centrum can be reconstructed after related titanosaurs as having been $105 \mathrm{~cm}$ long. Cross-scaling with Malawisaurus Jacobs et al. 1993, which has the most similar cervical vertebrae among titanosaurs known from complete cervical material, yields 
a total neck length of $9 \mathrm{~m}$.

Table 1 lists a selection of sauropods, mostly known from complete or nearly complete necks, showing how they vary in length, cervical count, centrum length, cervical rib length, and maximum elongation index.

\section{FACTORS ENABLING LONG NECKS}

Discounting the aquatic plesiosaurs, whose necks were subject to different forces from those of terrestrial animals, neck-length limits in the range of two to three meters seem to apply to every group except sauropods, which exceeded this limit by a factor of five. Whatever mechanical barriers prevented the evolution of truly long necks in other terrestrial vertebrates, sauropods did not just break that barrier - they smashed it. Since four separate sauropod lineages evolved necks three or four times longer than those of any of their rivals, it seems likely that sauropods shared a suite of features that facilitated the evolution of such long necks. What were these features?

\section{Absolutely Large Body Size}

It is obviously impossible for a terrestrial animal with a torso the size of a giraffe's to carry a 10 m neck. Sheer size is probably a necessary, but not sufficient, condition for evolving an absolutely long neck. Mere isometric scaling would of course suffice for larger animals to have longer necks, but Parrish (2006, p. 213) found a stronger result: that neck length is positively allometric with respect to body size in sauropods, varying with torso length to the power 1.35. This suggests that the necks of super-giant sauropods may have been even longer than imagined: Carpenter (2006, p. 133) estimated the neck length of the apocryphal giant Amphicoelias fragillimus Cope 1878 as 16.75 m, 2.21 times the length of 7.5 m used for Diplodocus, but if Parrish's allometric curve pertained then the true value would have been $2.21^{1.35}=2.92$ times as long as the neck of Diplodocus, or $21.9 \mathrm{~m}$; and the longest single vertebra would have been 187 cm long.

The allometric equation of Parrish (2006) is descriptive, but does not in itself suggest a causal link between size and neck length. As noted by Wedel et al. (2000b, p. 377), one possible explanation is that, because of their size, sauropods were under strong selection for larger feeding envelopes, which drove them to evolve longer necks.

\section{Quadrupedal Stance}

One of the key innovations in the evolution of sauropods was quadrupedality, facilitated by characters such as forelimb elongation, columnar limbs and short metapodials (Wilson and Sereno 1998, p. 24). As well as providing a platform for the evolution of large body size, the stability of the quadrupedal posture also enabled the evolution of longer necks: although progressive elongation displaced the centre of mass forwards from above the hindlimbs, it remained in the stable region between fore and hindlimbs.

Computer modelling shows that theropod dinosaurs such as Tyrannosaurus rex Osborn 1905 attained masses of 7 or even 10 tonnes (Hutchinson et al. 2011), and other giant theropods including Therizinosaurus and Gigantoraptor were probably of comparable size. However, they 
did not evolve necks as long as those of sauropods with similar mass, probably in part for this reason: the increased moment caused by neck elongation in a biped must be counteracted by an equal moment caused by a longer or more massive tail, increasing the physiological cost.

\section{Small Head}

Sauropods inherited proportionally small heads from ancestral sauropodomorphs, and continued to reduce their proportional size. In many clades, they were further lightened by reduced dentition, because unlike other large-bodied animals such as hadrosaurs, ceratopsians and elephants, sauropods did not orally process their food. Sauropod heads were simple cropping devices with a brain and sense organs, and did not require special equipment for obtaining food, such as the long beaks of azhdarchids (Chure et al. 2010, pp. 388-389). The reduction in head weight would have reduced the required lifting power of the necks that carried them, and therefore the muscle and ligament mass could be reduced, allowing the necks to be longer than would have been possible with heavier heads. Other groups of large-bodied animals have not evolved long necks, instead either developing large heads on short necks (ceratopsians, proboscideans, tyrannosaurs) or a compromise of a medium-sized head on a medium-length neck (hadrosaurs, indricotheres). It is significant that all other clades of large ( $>10$ ton) terrestrial herbivores - ceratopsians, hadrosaurs, proboscideans, and indricotheres — practiced extensive oral processing of their food, requiring massive dentition and correspondingly large heads.

\section{Numerous Cervical Vertebrae}

Many groups of animals seem to be constrained as to the number of cervical vertebrae they can evolve. With the exceptions of sloths and sirenians, mammals are all limited to exactly seven cervicals due to developmental constraints: mutations to the Hox genes that control the number of cervicals also give rise to neonatal cancer and other birth defects (Galis 1999, Galis and Metz 2003). Azdarchids are variously reported as having seven to nine cervical vertebrae, but never more; non-avian theropods do not seem to have exceeded the 13 or perhaps 14 cervicals of Neimongosaurus Zhang et al. 2001, with eleven or fewer being more typical.

By contrast, sauropods repeatedly increased the number of their cervical vertebrae, attaining as many as 19 in Mamenchisaurus hochuanensis (Young and Zhao 1972, p. 3-7). Modern swans have up to 25 cervical vertebrae, and as noted above the marine reptile Albertonectes had 76 cervical vertebrae. Multiplication of cervical vertebrae obviously contributes to neck elongation.

\section{Elongate Cervical Vertebrae}

The shape of cervical vertebrae is quantified by the elongation index (EI), defined by Wedel et al. (2000b, p. 346) as the anteroposterior length of the centrum divided by the midline height of its posterior articular face. As shown in Table 1, EI in sauropods routinely exceeded 4.0, and in some cases exceeded 6.0: Sauroposeidon C6 attained 6.1, and Erketu Ksepka and Norell 2006 C5 attained 7.0.

A similar degree of elongation is approached by the ostrich, in which C12 can attain an EI of 4.4 (measured from Mivart 1874, figure 29), and by the giraffe, in which the axis can attain an EI of 4.71 (personal measurement of FMNH 34426). It is greatly exceeded by azhdarchid pterosaurs, among which C5 of Quetzalcoatlus Lawson 1975 can attain an astonishing 12.4 
(measured from Witton and Naish 2008, figure 4c) and an isolated cervical from the Hell Creek Formation might have achieved 15 (measured from Henderson and Peterson 2006, figure 3).

But other long-necked groups are more limited in their elongation of individual vertebrae. Paraceratherium seems have been limited to about 3.3 for C2 (measured from Granger and Gregory 1936, figure 7) and much less for the other vertebrae. Elongation indexes of therizinosaurs such as Therizinosaurus probably did not greatly exceed 1.0 (measured for Nanshiungosaurus from Dong 1979, figures 1-2); those of oviraptorosaurs such as Gigantoraptor, 2.0 (measured from a photograph by MJW of referred specimen IGM 100/1002 of Khaan mckennai Clark et al. 2001). The very numerous vertebrae of Elasmosaurus are not very elongate, mostly having an EI around 1.0 and not exceeding about 1.4 (measured from Sachs 2005, figure 4).

\section{Air-Sac System}

One limiting factor on neck length is the difficulty of breathing through a long trachea. If the trachea is narrow, then it is difficult to inhale sufficient air quickly - a problem exacerbated by friction of inhaled air against the tracheal wall. But if the trachea is wider, its volume is increased, and a larger quantity of used air in the "tracheal dead space" is re-inhaled in each breath, reducing the oxygen content of each breath.

For this reason, it would be reasonable to expect animals to evolve the shortest possible trachea. However, in one clade - birds - an elongate trachea is not unusual, having evolved in swans (Banko 1960), cranes (Johnsgard 1983), moas (Worthy and Holdaway 2002), birds-of-paradise (Frith 1994) and several other groups. This trend reaches its peak in the trumpet manucode Phonygammus keraudrrenii (Clench 1978). In some mature males, the trachea coils back on itself so many times that its total length exceeds $800 \mathrm{~mm}$, nearly three times the total body length of approx. $30 \mathrm{~cm}$. Alone among extant animals, birds are able to cope with such extreme tracheal elongation, due to their very efficient lungs and the large tidal volume of the whole respiratory system on account of the voluminous air-sacs.

It is now well established that sauropods had an air-sac system similar to that of extant birds (Wedel 2003), and most likely a similarly efficient flow-through lung (Wedel 2009). These features would have greatly eased the problem of tracheal dead space, facilitating the evolution of longer necks. The air-sac system, including cervical air-sacs and extensive cervical diverticula running the full length of the neck, would also have served to lighten long necks.

Among other long-necked animals, theropods (including Therizinosaurus and Gigantoraptor) and pterosaurs also had had air-sac systems; but the mammals (giraffes, Paraceratherium) did not. However, whales provide an example suggesting it is unlikely that the evolution of long necks in terrestrial mammals has been limited by tracheal dead space. In a male sperm whale (Physeter) with a total body length of $16 \mathrm{~m}$, the length of the head is $5.6 \mathrm{~m}$ (Nishiwaki et al. 1963, cited in Cranford 1999, table 1). The largest sperm whales are up to $20 \mathrm{~m}$ in total body length (Gosho et al. 1984), which would give a head length of $7 \mathrm{~m}$ if these largest individuals scaled isometrically with the 16-m whales. However, the head length of sperm whales is positively allometric and increases with age even in adults (Cranford 1999, p. 1141 and figure 4), so a 20-m adult might well have a head slightly more than $7 \mathrm{~m}$ long. As in all cetaceans, the skull 
of a sperm whale is separated from the ribcage by the highly compressed cervical series. Finally, the nasal airways in sperm whales do not take a direct path from the blowhole to the lungs but describe sinuous curves through the head (Cranford 1999, figures 1 and 3). In a sperm whale with a 7-m head, the internal convolution of the nasal airways and the addition of the trachea spanning from the head to the trunk would give the path from blowhole to lungs a total length of perhaps 9 $\mathrm{m}$, showing that tracheae at least that long are possible without an air sac system.

\section{Vertebral Architecture}

Aside from the factors previously discussed, the elongation of sauropod necks was made possible by the distinctive architecture of their cervical vertebrae. The various aspects of their architecture are discussed in detail in the next section.

\section{ARCHITECTURE OF SAUROPOD NECKS}

\section{Pneumaticity of Cervical Vertebrae}

Not only did sauropods have a soft-tissue diverticular system, but the diverticula often invaded the vertebrae, leaving extensive excavations and other traces (e.g., Janensch 1947; Wedel et al. 2000b). Indeed, it is from the latter that we are able to infer the former.

The air space proportion (ASP) of a bone is the proportion of its volume taken up by pneumatic cavities (Wedel 2005). Dicraeosaurids (Dicraeosaurus, Amargasaurus, and related taxa) had reduced postcranial pneumaticity compared to other neosauropods, both in terms of the number of presacral vertebrae that were pneumatized, and in the air space proportion (Schwarz and Fritsch 2006). The presacral vertebrae of most neosauropod taxa had ASPs between 0.50 and 0.70 (Table 2) - as lightly built as the pneumatic bones of most birds (Wedel 2005). Basal sauropods outside or near the base of Neosauropoda, such as Cetiosaurus, Jobaria, and Haplocanthosaurus, had much lower ASPs, around 0.40. (ASPs of Cetiosaurus and Jobaria are estimates based on personal observations of the holotypes and referred specimens, and comparisons to CT scans of similarly-constructed Haplocanthosaurus vertebrae.)

The effects of pneumatization on the mass of the cervical series have been little explored. The centrum walls, laminae, septae, and struts that comprised the vertebrae were primarily made of compact bone (Reid 1996). The specific gravity (SG) of compact bone is 1.8-2.0 in most tetrapods (Spector 1956), so an element with an ASP of 0.60 (and therefore a compact bone proportion of 0.40 ) would have an in-vivo SG of 0.7-0.8. Some sauropod vertebrae were much lighter. For example, Sauroposeidon has ASP values up to 0.89 and therefore SG as low as 0.2 in some parts of its vertebrae. On the other hand, many basal sauropods had ASPs of $0.30-0.40$ and therefore SG of 1.1-1.4.

An important effect of postcranial pneumaticity is to broaden the range of available densities in skeletal construction. Animals without postcranial pneumaticity, including mammals and ornithischian dinosaurs, are constrained to build their skeletons out of bone tissue (SG = 1.8- 2.0) and marrow (SG = 0.93; Currey and Alexander 1985, p. 455). Therefore, the whole-element densities of their postcranial bones will always be between 1.0 and 2.0; they cannot be more dense than bone tissue, nor can they be constructed entirely out of marrow. The pneumatic bones 
of pterosaurs and saurischian dinosaurs are made of bone tissue (SG = 1.8-2.0) and air space (SG $=0$ ), which allows them to have whole-element densities that are much lower. The lightest postcranial bones for which data are available are those of Sauroposeidon and some pterosaurs. The cranial bones of some birds are even lighter. Seki et al. (2005) reported an SG of 0.05 for the "bone foam" inside the beak of the toucan (Rhamphastos toco), and an SG of 0.1 for the entire beak. To date, this is the lightest form of bone known in any vertebrate.

While the impact of soft-tissue diverticula is more difficult to assess, it is easy to imagine that the density of a typical neosauropod neck may have been less than $0.5 \mathrm{~kg} / \mathrm{dm}^{3}$. Although pneumaticity was undoubtedly an important adaptation for increasing the length of the neck without greatly increasing its mass, a longer neck remains more mechanically demanding than a shorter neck of the same mass, because that mass acts further from the fulcrum of the cervicodorsal joint, increasing the moment that must be counteracted by the epaxial tension members. Also, longer trachea and blood vessels cause physiological difficulties: weight support is only one of the problems imposed by a long neck.

While pneumaticity may be necessary for the development of a long neck, it is clearly not sufficient: while three groups of theropods, all pneumatic, evolved necks in the 2-2.5 m range, and pneumatic pterosaurs attained $3 \mathrm{~m}$, these remain well short of even the less impressive sauropod necks (e.g., 4 m in Camarasaurus AMNH 5761; Osborn and Mook 1921).

\section{Extent of Soft-Tissue relative to Size of Vertebrae}

In most extant vertebrates including birds and crocodilians, the diameter of the neck is three or four times that of the cervical vertebrae that form its core. Even in long, thin-necked animals such as the ostrich, the muscular part of the neck is twice as wide and 2.3 times as tall as the enclosed vertebra (Fig. 4.1), and if the trachea and skin and included the soft-tissue is included the dorsoventral thickness of the neck is fully 3.3 times that of the vertebra alone (Dzemski and Christian 2007, figure 2). (In the caption to Wedel [2003, figure 2], from which Fig. 4.1 of the present paper is modified, the small airspace ventral to vertebra was misidentified as the trachea. In fact it is a complex of diverticula around the carotid arteries.)

If the necks of sauropods were as heavily muscled as those of ostriches, then they would have appeared in cross section as shown in Fig. 4.2. But life restorations of sauropods going back to the 1800 have been unanimous that this cannot have been the case in sauropods, as such over-muscled necks would have been too heavy to lift; and the various published reconstructions of sauropod neck cross sections (e.g., Paul 1997, figure 4; Schwarz et al. 2007, figure 7, pp. 8A, $9 \mathrm{E}$ ) all agree in making the total diameter including soft-tissue only 105-125\% that of the vertebrae alone.

This is a consequence of scaling, which makes it impossible for sauropod necks to be similar to those of ostriches. Consider an ostrich neck scaled up by a linear factor of L. The weight exerted by the neck is proportional to $\mathrm{L}^{3}$ but the cross-sectional area of the bracing members is proportional to only $\mathrm{L}^{2}$. Stress is force/area, which is proportional to $\mathrm{L}^{3} / \mathrm{L}^{2}=\mathrm{L}$, so the stress on the bracing members that support the neck varies linearly with L. (The weight of the neck acts at a distance proportional to $\mathrm{L}$ from the torso, and the bracing members acts at a distance proportional to $\mathrm{L}$ above the neck-torso articulation, so these factors cancel out of the balancing 
moment equation.) Since isometric similarity is precluded the necks of sauropods had to be re-engineered in order to attain such great sizes. Can that have been done by reducing the amount of muscle?

In fact, comparing the restored neck of a sauropod with that of an ostrich scaled to the same body size, it is apparent that the sauropod neck has not so much reduced the size of the neck muscles as increased the size of the cervicals vertebrae themselves (Fig. 4.3): they are much larger compared to the torso than in the ostrich. Simply increasing the size of the vertebrae would not be a good strategy for neck support, because bone is the densest material in the body apart from tooth enamel and dentine. But as noted above, sauropod vertebrae were very pneumatic, typically consisting of $60 \%$ air. In effect, sauropods inflated their vertebrae within the muscular envelope of the neck, moving the bone, muscle and ligament away from the centre so that they acted with greater mechanical advantage: higher epaxial tension members, lower hypaxial compression members, and more laterally positioned paraxials.

\section{Muscle Attachments}

In extant animals, the mechanically significant soft tissues of the neck (muscles, tendons and ligaments) can be examined and their osteological correlates identified. In extinct animals, except in a very few cases of exceptional preservation, only the fossilized bones are available: but using extant animals as guides, osteological features can be interpreted as correlates of the absent soft tissue, so that the ligaments and musculature of the extinct animal can be tentatively reconstructed (Bryant and Russell 1992; Witmer 1995). In order to do this for sauropods, it is necessary first to examine their extant outgroups, the birds and crocodilians.

In all vertebrates, axial musculature is divided both into left and right sides and into epaxial and hypaxial (i.e., dorsal and ventral to the vertebral column) domains, yielding four quadrants. In birds, the largest and mechanically most important epaxial muscles (M. longus colli dorsalis and $\mathrm{M}$. cervicalis ascendens) insert on the epipophyses of the cervical vertebrae - that is, distinct dorsally projecting tubercles above the postzygapophyses. The large hypaxial muscles (M. flexor colli lateralis, M. flexor colli medialis, and M. longus colli ventralis) insert on the cervical ribs (Fig. 5; Baumel et al. 1993; Tsuihiji 2004). The osteology of the cervical vertebrae makes mechanical sense; the major muscle insertions are prominent osteological features located at the four "corners" of the vertebrae (Fig. 6.1). Non-avian theropods resembled birds in this respect, having prominent epipophyses and sizable cervical ribs, which point in the four expected directions (Fig. 6.2).

The cervical architecture is rather different in crocodilians, and in non-archosaurian diapsids such as lizards, snakes, ichthyosaurs and plesiosaurs: there are no epipophyses, and the main epaxial neck muscles are the Mm. Interspinales, which attach to the neural spines rather than to epipophyses (Fig. 6.3). In most sauropods, the cervical vertebrae do have epipophyses, but the neural spines are as prominent or more so (Fig. 6.4). In this respect, sauropod osteology is intermediate between the conditions of crocodilians and birds - so the widely recognized similarity of sauropod cervicals to those of birds (e.g., Wedel and Sanders 2002; Tsuihiji 2004), while significant, should not be accepted unreservedly. Since the prominent neural spine serves as the primary attachment site for epaxial muscles in most theropod outgroups, the condition in birds and other theropods is derived; that of sauropods retains aspects of the primitive condition. 
Although sauropods shared a common bauplan, their morphological disparity was much greater than has usually been assumed (Taylor and Naish 2007, pp. 1560-1561). This disparity is particularly evident in the cervical vertebrae (Fig. 7). Those of Apatosaurus Marsh 1877, for example, are anteroposteriorly short and dorsoventrally tall, and have short, robust cervical ribs mounted far ventral to the centra; the cervical centra of Isisaurus colberti Jain and Bandyopadhyay 1997 are even shorter anteroposteriorly, but have more dorsally located cervical ribs; by contrast, the cervical vertebrae of Erketu ellisoni Ksepka and Norell 2006 are relatively much longer and lower, and have long, thin cervical ribs mounted only slightly ventral to the centra, which are sigmoid rather than cylindrical. Towards the middle ground of these extremes fall the cervical vertebrae of Giraffatitan which are anteroposteriorly longer and dorsoventrally shorter than those of Apatosaurus, but not as anteroposteriorly long or as dorsoventrally short as those of Erketu. In light of the demanding mechanical constraints that were imposed on sauropods, it is surprising that their necks vary so much morphologically, with different lineages having evolved dramatically different solutions to the problem of neck elongation and elevation.

Interpretation of sauropods as living animals is made especially difficult by the lack of good extant analogues. Among animals with long necks, giraffes, camels, and other artiodactyls have very different cervical osteology and (we assume) myology, and even the longest of their necks, at about $2.4 \mathrm{~m}$, only one sixth the length attained by some sauropods. Birds are phylogenetically closer to sauropods, and some birds (e.g., swans and ostriches) have proportionally very long necks. Furthermore, the presence in most sauropods of epipophyses similar to those of birds suggests that sauropods were myologically similar to birds. However, the small absolute size of birds means that the forces acting on their necks are so different that we can't assume that sauropod necks functioned in the same ways - just as the problems involved in flight through air for high-Reynolds number fliers such as birds are very different than than they are for low-Reynolds number fliers such as fruit-flies, whose aerodynamics are dominated by friction drag rather than form drag.

Because sauropods were so much bigger than their relatives, and their necks so much longer, mechanical considerations in the construction of their necks were significantly more important than in their outgroups. Furthermore, the great size and shape disparity between sauropods and their outgroups means that interpretations of cervical soft-tissue anatomy in sauropods cannot be based purely on the extant phylogenetic bracket method: this alone would be no more informative than trying to determine the anatomy of elephants from that of manatees and hyraxes.

With all these caveats in mind, the best extant analogues for sauropod necks nevertheless remain those of birds: they are the only extant animals that share with sauropods epipophyses above their postzygapophyses, pronounced cervical ribs, and pneumatic foramina (Fig. 6.1, 6.4). The first two of these features were inherited from a common saurischian ancestor. The foramina seem to have been independently derived in birds, but this was possible because air sacs and soft-tissue pneumatic diverticula were likely present in the common saurischian ancestor (Wedel 2006b, 2007b). These observations enable us to draw conclusions about sauropod neck soft tissue beyond what the extant phylogenetic bracket would allow. Specifically, the epipophyses are osteological correlates of the M. longus colli dorsalis and $\mathrm{M}$. cervicalis ascendens epaxial muscles, which must therefore have been present in sauropods, although we can not conclude from this that they were necessarily the dominant epaxial muscles as they are in birds. 


\section{Neural Spines}

The neural spines and epipophyses of sauropods both anchored epaxial muscles, but as they were differently developed in different taxa, they were probably of varying mechanical importance in different taxa. For example, based on their relative heights, epipophyses probably dominated neural spines in Apatosaurus (Fig. 7.1) but neural spines may have dominated in Isisaurus Wilson and Upchurch 2003 and Giraffatitan (Fig. 7.3, 7.4). In some sauropods, including Erketu and Mamenchisaurus, which were proportionally long-necked even by sauropod standards, the neural spines are strikingly low, and the epipophyses no higher - a surprising arrangement, as low spines would have reduced the lever arm with which the epaxial tension members worked. Among these sauropods with low neural spines, some have rugose neurapophyses with spurs directed anteriorly and posteriorly from the tip of the spine (Fig. 8). These appear either to have anchored discontinuous interspinous ligaments, as found in all birds (see Wedel et al. 2000b, figure 20), or to have been embedded in a continuous supraspinous ligament, as found in the ostrich (Dzemski and Christian 2007, pp. 701-702).

In some sauropods, the cervical neural spines are bifid (i.e., having separate left and right metapophyses and a trough between them). This morphology appears to have evolved at least five times (in Mamenchisaurus, flagellicaudatans, Camarasaurus Cope 1877, Erketu and Opisthocoelicaudia Borsuk-Bialynicka 1977) with no apparent reversals (Wedel and Taylor, in review). This morphology, then, seems to have been easy for sauropods to gain, but difficult or perhaps impossible to lose. Bifid cervical vertebrae are extremely uncommon in other taxa, and among extant animals they are found only in birds: the ibis Theristicus Wagler 1832 (Tambussi et al. 2012) and ratites including Rhea americana Linnaeus 1758 (Tsuihiji 2004, figure 2B), Casuarius casuarius Brisson 1760 (Schwarz et al. 2007, figure 5B) and Dromaius novaehollandiae Latham 1790 (Osborn 1898, figure 1). It has often been assumed that in sauropods with bifid cervical spines, the intermetapophyseal trough housed a large ligament analogous to the nuchal ligament of artiodactyl mammals (e.g., Janensch 1929, plate 4; Alexander 1985, pp. 13-14; Wilson and Sereno 1998, p. 60). Such an arrangement seems unlikely, as lowering the ligament into the trough would reduce its mechanical advantage; however, this is similar to the arrangement seen in Rhea americana, in which branches of the "nuchal ligament" attach to the base of the trough (Tsuihiji 2004, figure 3). More direct evidence is found in ligament scars in the troughs of some diplodocids: these can be prominent, as in the doorknob-sized attachment site in the Apatosaurus sp. cervical OMNH 01341 (Fig. 9.1).

However, ligament cannot have filled the trough as envisaged by Alexander (1985, figure 4C), because pneumatic foramina are often found in the base of the troughs of presacral vertebrae, for example in the cervicals of Apatosaurus (Fig. 9.1) and the dorsal vertebrae of Camarasaurus sp. CM 584 (Fig. 9.2). In some specimens, a ligament scar and pneumatic foramen occur together in the intermetapophyseal trough (Fig. 9.1; Schwarz et al. 2007, figure 6E). Pneumatic diverticula are sometimes found between the centropostzygapophyseal laminae even in sauropods with non-bifid spines, as shown by the isolated brachiosaurid cervical MIWG 7306 from the Isle of Wight (Naish 2008), so the presence of soft-tissue diverticula in this location is probably primitive for Neosauropoda at least. In conclusion, while some ligament was undoubtedly present within the trough formed by the metapophyses of bifid neural spines, much of the space was probably filled with pneumatic diverticula. 
One possible advantage of bifid spines would be to increase the lateral leverage of the ligaments and muscles that attach to the metapophyses, enabling them to contribute to lateral stabilisation and motion as well as vertical. A cantilevered beam, which is what a sauropod neck is in mechanical terms, requires only a single dorsal tension member to stabilize it vertically, but two (one on each side) to stabilize it horizontally. A sauropod neck that was supported from above only by a single midline tension member would need additional horizontal stabilization from muscles and ligaments not directly involved in support.

Whatever the advantages of bifid spines, they were clearly not indispensable, as some sauropod lineages evolved very long necks with unsplit spines (e.g., brachiosaurids, culminating in Sauroposeidon, and most titanosaurs, including the very long-necked Puertasaurus). Even in taxa that do have bifid spines, they are rarely split through the whole series: for example, the first eight cervicals of Barosaurus do not have bifid spines (McIntosh 2005; MJW, pers. obs). Even in Camarasaurus lewisi BYU 9047, in which every postaxial cervical vertebra is at least partially bifid (McIntosh et al. 1996b), the bifurcation is very slight in the anterior cervicals and probably of little mechanical consequence. If bifid spines conferred a great advantage, they would presumably be found throughout the neck - although the importance of stability, and the difficulty of attaining it, is greater in the posterior part of the neck, which bears greater forces than the anterior part. Since bifid spines always occur together with unsplit spines, it seems likely that however they were used mechanically, it was probably not radically different from neural spine function in vertebrae with unsplit spines.

\section{Epipophyses}

As noted above, the epipophyses are the insertion points of the largest and longest epaxial muscles in birds, whereas in crocodilians the epipophyses are non-existent, and no major muscles insert above the postzygapophyses (Tsuihiji 2004). Epipophyses are found in most, though not all, sauropods and theropods. For example, they are absent in the titanosaurs Malawisaurus (pers. obs., MJW; Gomani 2005, figure 8) and Isisaurus (Fig. 7.3); but their presence in other titanosaurs such as Rapetosaurus Curry Rogers and Forster 2001 (Curry Rogers and Forster 2001, figure 3A) and Saltasaurus Bonaparte and Powell 1980 (Powell 1992, figure 5) and in outgroups such as Giraffatitan (Fig. 7.4) and Camarasaurus (Osborn and Mook 1921, plate LXVII, figure 9; McIntosh et al. 1996a, figure 29) indicates that their absences in Malawisaurus and Isisaurus, if not due to damage to the material, represent secondary losses. Not all muscles leave diagnostic traces on the skeleton, so the absence of epipophyses does not mean that the epaxial muscles that insert above the postzygapophyses were absent. It is worth noting that the available material of Malawisaurus and Isisaurus pertains to relatively small individuals; perhaps the forces exerted by the epaxial muscles were not enough to produce distinctive scarring of the bone that we would recognize as epipophyses.

The existence of epipophyses on the cervical vertebrae of most sauropods, together with those in theropods and birds, suggests that epaxial muscles were inserting above the postzygapophyses at least by the origin of Saurischia. Epipophyses are also known in basal ornithischians, e.g., Lesothosaurus Galton 1978 (Sereno 1991b, figure 8A) and Heterodontosaurus Crompton and Charig 1962 (Santa Luca 1980, figure 5A), and also in the basal pterosaur Rhamphorhynchus Meyer 1846 (Bonde and Christiansen 2003, figures 6-9), suggesting that these insertion points 
were in use at the base of Dinosauria and possibly Ornithodira.

In sauropods, the size and location of the epipophyses is variable: in C8 of Giraffatitan, the epipophyses are approximately half as high above the centrum as the neurapophysis (Fig. 7.4); in anterior cervicals of Erketu, the epipophyses are equally as high as the tips of the neural spines (Fig. 7.5), although the spines are higher in posterior cervicals. It is possible that in the posterior cervicals of some Apatosaurus ajax Marsh 1877 specimens, the epipophyses are higher than the metapophyses (Fig. 7.1), but it is difficult to be sure as the vertebrae that seem to most closely approach this condition are at least partly reconstructed in plaster (Barbour 1890, figure 1). In any event, it is clear from preserved sequences of Apatosaurus cervicals (Gilmore 1936, plate XXIV; Upchurch et al. 2005, plate 1) that in this genus the neural spines are proportionally higher relative to the epipophyses in the anterior cervicals than in the posterior. The trend is opposite in Erketu, in which the epipophyses increasingly dominate neural spines anteriorly. This further demonstrates the variety of different mechanical strategies used by different sauropods to support their long necks. In those sauropods without ostensible epipophyses, phylogenetic bracketing nevertheless suggests that muscles did insert above the postzygapophyses, but the insertions are not marked by obvious scars or processes and these muscles were probably less important than those attached to the spine.

\section{Cervical Ribs}

In extant birds, cervical ribs are the insertion points for the $\mathrm{M}$ flexor colli lateralis, $\mathrm{M}$ flexor colli medialis and M longus colli ventralis hypaxial muscles (Zweers et al. 1987; Baumel et al. 1993; see also Fig. 5). No bird has cervical ribs long enough to overlap, but the tendons that insert on the cervical ribs do overlap and are free to slide past each other longitudinally. In less derived saurischians, including sauropods, the ventral tendons are ossified into long, overlapping cervical ribs (Klein et al. 2012) which are secondarily shortened to less than a centrum length in Diplodocoidea and in Maniraptoriformes, including birds. The null hypothesis is that the long cervical ribs of theropods and sauropods functioned similarly to the short cervical ribs and long tendons of birds, as the insertions of long hypaxial muscles. However, some aspects of muscle insertion in sauropod necks are mysterious and may be illuminated by closer comparisons to their extant relatives.

In birds, ossification (or at least mineralization) of tendon has many functional effects: it (1) restricts tendon deformation; (2) reduces tendon strain at a given stress; (3) accommodates higher load bearing (to a point; see below); and (4) reduces damage to the tendon (Landis and Silver 2002, p. 1153). In general, proportionally longer and thinner tendons are more extensible and allow more elastic recoil, and shorter, thicker tendons are less extensible and provide less elastic recoil (Biewener 2008, pp. 272-274). Mineralization or ossification reduces the extensibility of a tendon, and can allow a long, thin tendon to behave more like a short, thick one. Ossified tendons in the lower limbs of birds are typically found distal to the knee (Hutchinson 2002, p. 1071), where the tendons are constrained to be long and thin by the overall construction of the limb; ossification may be the only viable way for birds to advantageously shift the mechanical properties of these tendons.

The long hypaxial tendons in the necks of sauropod dinosaurs may have been similarly constrained. Ossification of the hypaxial tendons into long cervical ribs may have provided 
several benefits for sauropods:

- Long tendons move the bulk of the hypaxial neck muscles closer to the base of the neck, which reduces the lever arm of the neck mass. Tendon has a much lower Young's modulus than bone, and reducing the elastic recoil of the hypaxial tendons would have allowed the hypaxial muscles of sauropods to more directly affect the vertebrae to which they were attached. Reduced tendon elasticity is known to improve position control of the involved muscles (Alexander 2002, p. 1009).

- It has been suggested (Wedel et al. 2000b, p. 380) that elongate cervical ribs may have played a role in ventrally stabilizing the neck, i.e., preventing involuntary dorsal extension by contracting antagonistically against the stronger epaxial tension members (which had to counteract gravity in addition to shifting the mass of the neck).

- Stiff cervical ribs would have helped provide lateral stabilization for the neck, which would have been especially important in taxa with epaxial tension members concentrated on the midline (i.e., those with non-bifid spines) as discussed above.

- Stiff cervical ribs would have provided resistance against torsion of the neck.

(It has also been suggested by Martin et al. [1998] that the cervical ribs of at least some sauropods functioned as incompressible ventral bracing members. But this hypothesis is badly flawed - see Wedel et al. 2000b, p. 379-380, Wedel et al., in prep. and Klein et al. 2012)

If either of the first two hypotheses is accurate, it is difficult to understand why diplodocids evolved apomorphically short cervical ribs, especially long-necked forms such as Barosaurus and Supersaurus. If the primary role of long cervical ribs was in providing lateral stabilization for taxa with midline epaxial tension members, then the need for this stabilization would be reduced in forms with bifid spines, such as diplodocids, which shifted their epaxial tension members laterally as they were attached to the metapophyses. This, however, would raise the question of why other taxa with bifid spines (e.g., Camarasaurus) also retained elongate cervical ribs, and in the case of Mamenchisaurus apparently evolved apomorphically long cervical ribs (Russell and Zheng 1993, pp. 2089-2090). It may be that these taxa retained their epaxial tension members primarily on the midline, in the intermetapophyseal trough, while diplodocids shifted theirs laterally; but we know from osteological evidence (see above) that at least some diplodocids did have ligaments or muscles anchored within the trough. Mallison (2011, p. 238) suggested that the short cervical ribs of diplodocids could be an adaptation for neck flexibility. This would be useful in tripodal feeding in dense canopies - a behaviour that their hips and hindlimbs were adapted for.

Apatosaurus presents a final riddle regarding cervical ribs. Even among diplodocids, it had extraordinary cervical ribs: very short, very robust, and positioned very low, far below the centra on extremely long parapophyses (Fig. 7.1, 7.2), so that the neck of Apatosaurus must have been. triangular in cross-section. What function can the ribs have evolved to perform? They were much too short to have functioned efficiently in horizontal or vertical stabilization, and in any case seem over-engineered for these functions. It is tempting to infer that the autapomorphies of the neck in Apatosaurus are adaptations for some unique aspect of its lifestyle, perhaps violent intraspecific combat similar to the "necking" of giraffes. Even if this were so, however, it is 
difficult to see the benefit in Apatosaurus excelsus (Marsh 1879a) of cervical ribs held so far below the centrum - an arrangement that seems to make little sense from any mechanical perspective, and may have to be written off as an inexplicable consequence of sexual selection or species recognition.

\section{Asymmetric Elongation of Cervical Ribs and Epipophyses}

A central paradox of sauropod cervical morphology is that in the elongation of the cervical ribs, the vertebrae appear better adapted for anchoring hypaxial than epaxial musculature - even though holding the neck up was important and, due to gravity, much more difficult than drawing it down. First, the cervical ribs present a greater area for muscle attachment than the epipophyses do; and second, the much greater length of the cervical ribs in most sauropods enabled the hypaxial musculature to be shifted backwards much further than the epaxial musculature, as the epipophyses are not elongate in any known sauropod. We know that posterior elongation of the epipophyses is developmentally possible in saurischians, because those in the tail of Deinonychus Ostrom 1969a are extended to the length of a centrum (Ostrom 1969b, figure 37). Fig. 10 shows the cervical skeleton of Euhelopus as it actually is, and reconstructed with speculative muscle attachments that would have been more mechanically efficient: why did sauropod necks not evolve this way? In fact, there are several likely reasons.

- $\quad$ First, positioning and moving the neck for feeding would have required fine control, and precise movements requires short levers.

- Second, although bone is much stiffer than tendon, it is actually not as strong in tension, so that an ossified tendon is more likely to break under load.

- Third, muscles expand transversely when contracted lengthways. For epaxial muscles in sauropods necks, this expansion would strongly bend ossified epipophyseal tendons, subjecting them to greater stress than simple longitudinal tension. (The same effect would also have caused some bending of cervical ribs, but the lower stresses in ventral musculature would have reduced the effect.)

\section{Short Neural Spines in Long Necks}

In many cases, the sauropods with the proportionally longest necks are also those whose necks superficially make the least mechanical sense. It is particularly notable that mamenchisaurids (Mamenchisaurus and Omeisaurus) have very low neural spines, as does Erketu in the preserved, anterior, cervicals. Since excessively long neural spines would impede neck extension by overlapping with each other, as in dicraeosaurids, shorter spines would be advantageous for improving neck flexibility. But these low spines would have reduced the lever arm with which epaxial tension members acted.

A speculative explanation, at least, can be offered. Counter-intuitively, the height above the centrum at which a muscle of given size acts has no effect at all on its ability to move the vertebra through a given arc. Although muscles attached to a short spine need to exert greater force to allow for the shorter lever arm, they correspondingly need contract a shorter distance in order to raise the neck by the same amount. Low neural spines, then, may have been connected by strongly pennate muscles, able to contract very forcefully but only over a short distance. 
In an animal adopting this low-spine strategy to neck elongation, the difficulty is simply one of fitting the muscle into the space available. A lower limit to neural spine length is imposed by the volume of muscle needed to produce the range of motion. (Raising the neck is work, and while the force exerted by a muscle is proportional to its cross-sectional area, the work it can do varies with volume, so shorter muscles need a correspondingly larger cross-sectional area.)

Another possibility is that taxa with short spines had shifted almost all of their epaxial muscle attachments to the epipophyses, as with the long dorsal muscles of birds. In birds, the long multisegment epaxial muscles are free to "bowstring" across the dorsal curvature at the base of the neck (van der Leeuw et al. 2001, figure 5). Short neural spines do not indicate poor mechanical advantage for these muscles, because they act at high angles of inclination to the long axis of each vertebra. Tall neural spines increase mechanical advantage of muscles when the vertebrae are held horizontally, but this is unlikely to have been a common posture for sauropods (Taylor et al. 2009).

\section{Homology and Analogy of Vertebral Features}

Bony attachment sites for the large cervical muscles have varied along the evolutionary line from basal amniotes to birds (Fig. 11). In extant lizards and crocodilians, as in basal archosaurs (Fig. 11.1), the neural spine is very large and anchors essentially all of the large multisegment epaxial muscles (Tsuihiji 2005, figure 2), and there are no epipophyses at all. However, in extant birds, as in non-avian theropods (Figs. 11.4, 11.5), the epipophyses are more prominent and significant than the neural spines and serve as insertion points for all of the multisegment dorsal muscles. The very short neural spines serve as the origins of long dorsal muscles running anteriorly from each vertebra, but the only muscles that insert on the spines and adjacent bony ridges are the small and short $\mathrm{Mm}$. interspinales and $\mathrm{Mm}$. intercristales.

In intermediate forms such as sauropods the situation is more complex, as both the neural spines and epipophyses are prominent - to varying degrees in different species. In sauropods with unsplit neural spines, such as Giraffatitan (Fig. 11.2), the muscles of the neural spine were presumably significant, and would have acted primarily along the midline of the neck. The muscles of the epipophyses were also present, but because their insertions are positioned laterally, the action of these muscles would have functioned both in support and in lateral movement. In sauropods with bifid neural spines, such as Camarasaurus (Fig. 11.3), the muscles inserting on the neural spine were also laterally displaced, so that they as well as the $\mathrm{Mm}$. longus colli dorsalis would have had the dual function of support and lateral motion. In sauropods with bifid spines, then, the one- or two-segment $\mathrm{Mm}$. intercristales and $\mathrm{Mm}$. interspinales shared the function of lateral stabilization and movement with the multisegment $\mathrm{Mm}$. longus colli dorsalis.

It is tempting to imagine an evolutionary pathway in which bifurcation of neural spines was an intermediate step in the evolutionary shift of the insertions of the large multisegment epaxial muscles from the neural spine to the epipophyses. However, this explanation cannot be correct, as bifid spines are not known in taxa along the line to birds - only in sauropods and a few modern birds. This is particularly clear in Fig. 11.4, where a small neural spine remains in the cervical of Majungasaurus, but is dominated by epipophyses. The sequence instead seems simply have been one of progressive reduction of the neural spine and enlargement of the epipophyses. The outcome of this evolutionary sequence, as shown in Fig. 11.5, is that from a myological 
perspective, modern birds have functionally bifid neural spines: that is, their vertebrae have evolved in a way that is analogous with the true bifid spines of sauropods even though it is not homologous.

\section{CONCLUSIONS: WHY GIRAFFES HAVE SUCH SHORT NECKS}

Reviewing the characters that facilitate the evolution of extremely long necks, it is apparent that only sauropods have them all (Table 3). Although the necks of giraffes are the longest of any extant animals, they are shorter by a factor of six than those of the longest sauropods, because giraffes have relatively small torsos, relatively large, heavy heads, only seven cervical vertebrae, no air-sac system and no vertebral pneumaticity. Absence of elongated cervical ribs may also impede neck elongation. In defence of giraffes, they are relative latecomers in evolutionary terms: given a few tens of millions more years, it is conceivable that they might overcome some of these disadvantages to evolve longer necks. But in some respects they seem locked into a mammalian pattern that will always prevent them from matching the necks of sauropods: extensive oral processing of food requires a large head with heavy teeth; almost no mammal has evolved more than seven cervical vertebrae; and the mammalian lung has attained a local maximum of efficiency that makes it unlikely ever to evolve into something analogous to the avian flow-through lung, so both and air-sac system and vertebral pneumaticity are precluded.

Similarly, ostriches seem unlikely ever to evolve really long necks, despite the prerequisite small heads and avian lung, simply because they are small bipeds. Birds seem unable to attain sizes exceeding the $500 \mathrm{~kg}$ of the "elephant bird" Aepyornis maximus, probably because adult body size and egg size, which were not tightly correlated in non-avian dinosaurs, are correlated in birds (Birchard and Deeming 2009, Deeming and Birchard 2009). There are strong mechanical constraints on the latter: as body size increases, the eggs approach a point at which the shell cannot simultaneously be thick enough to support the egg and thin enough for the hatchling to break out of (Murray and Vickers-Rich 2004, p. 212, Birchard and Deeming 2009).

Some of the other long-necked taxa listed in Table 3 seem to have been better equipped to evolve longer necks. It is impressive that the azhdarchid pterosaurs seem likely to have achieved $3 \mathrm{~m}$ while retaining flight: no doubt their pneumaticity was a key feature in making this possible in spite of their large heads. Nevertheless, the absolute size constraints imposed by flight make it unlikely that pterosaurs would have greatly exceeded this mark even had they survived the end-Cretaceous extinction.

The three theropod clades mentioned above (ornithomimosaurs, therizinosaurs and to a lesser extent oviraptorosaurs) appear to have had small heads, proportionally similar in size to those of sauropods, as well pneumatic systems that invaded their vertebrae. Why did they not evolve necks as long as those of sauropods? Possible reasons include the following:

- All theropods were bipedal, and the demands of bipedal locomotion may have prevented them from evolving the giant body sizes that are required for very long necks.

- The long-necked theropods may not have been under the same selection pressure to evolve long necks as were sauropods. If they were omnivorous, for example, then their use of more nutritious food may have mitigated the need for increased feeding envelopes. Among extant theropods, the ostrich is proportionally long-necked but feeds mostly from the ground 
(Dzemski and Christian 2007), and so has no selective pressure to evolve a yet longer neck.

- All of the largest long-necked theropods lived in the Late Cretaceous, two of them in the Campanian-Maastrichtian. Had they not died out at the end of the Cretaceous, they might have gone on to attain larger size. On the other hand, sauropods attained large size very quickly in evolutionary terms, with a $104 \mathrm{~cm}$ humerus from the late Norian or Rhaetian indicating a Camarasaurus-sized sauropod only about ten million years after the first known dinosaurs (Buffetaut et al. 2002b). If theropods did not evolve larger body size in the 150 million years available to them, it seems likely that they did not have the potential to do so.

- Finally, it should be noted that all three of the long-necked theropods discussed above are known from incomplete remains that do not include any informative cervical material. It is possible that neck length was positively allometric in these clades, as in sauropods, and they may have had necks somewhat longer than isometric scaling suggests.

In summary, no other clade has all of the suggested adaptations for long necks that are found in sauropods. Were it not for the end-Cretaceous extinction, non-avian theropods would have been the most likely candidates for evolving sauropod-like neck lengths, due to the combination of pneumaticity, small heads in some clades. and potential for large body size. 


\section{ACKNOWLEDGMENTS}

We thank R. L. Cifelli, N. J. Czaplewski, and J. Person (Oklahoma Museum of Natural History), D S. Berman, M. C. Lamanna, and A. C. Henrici (Carnegie Museum of Natural History), B. B. Britt, K. L. Stadtman, and R. D. Scheetz (Brigham Young University), L. L. Jacobs and D. A. Winkler (Southern Methodist University), and S. Hutt (Dinosaur Isle) for access to specimens. D. T. Ksepka (American Museum of Natural History) provided high-resolution versions of the figures from his description of Erketu and L. P. A. M. Claessens (College of the Holy Cross) provided unpublished images of alligator vertebrae. D. M. Lovelace (Wyoming Dinosaur Center) provided a cross-sectional photo of a broken Supersaurus cervical for the ASP calculations. D. W. E. Hone investigated the status of the Omeisaurus junghsiensis material and allowed us to note his conclusion. M. P. Witton (University of Portsmouth) provided helpful discussion on pterosaur necks. W. I. Sellers (University of Manchester) clarified our understanding of mechanical advantage. We used translations of several papers from the Polyglot Paleontologist web-site (http://www.paleoglot.org/index.cfm). We thank Scott Hartman for kindly allowing us to use several of his skeletal reconstructions in parts of Figures 1 and 2; and "kei" and Kevin Ryder for permission to use their photographs. This paper has been reviewed by at least eight referees at various times. We thank those who provided useful feedback and helpful contributions - in particular H. Mallison (Museum für Naturkunde Berlin) and the anonymous referee who also reviewed this version. Finally we thank J. Hutchinson (Royal Veterinary College) for his constructive and efficient editorial handling of the manuscript. 


\section{REFERENCES}

Alexander, R.M. 1985. Mechanics of posture and gait of some large dinosaurs. Zoological Journal of the Linnean Society, 83:1-25.

Alexander, R.M. 2002. Tendon elasticity and muscle function. Comparative Biochemistry and Physiology, Part A, 133:1001-1011.

Arambourg, C. 1959. Titanopteryx philadelphiae nov. gen., nov. sp., ptérosaurien géant. Notes et Mémoires sur le Moyen-Orient, 7:229-234.

Banko, W.E. 1960. The Trumpeter Swan. North American Fauna Series, No. 63., US Fish and Wildlife Service, Washington, D.C.

Barbour, E.H. 1890. Scientific News: 5. Notes on the Paleontological Laboratory of the United States Geological Survey under Professor Marsh. The American Naturalist, 24:388-400.

Barsbold, R. 1976. New information on Therizinosaurus (Therizinosauridae, Theropoda), p. 76-92. In Kramarenko, N.N,, Luvsandansan, B., Voronin, Y.I., Barsbold, R., Rozhdestvensky, A.K., Trofimov, B.A. and Reshetov, V.Y. (eds.), Paleontology and Biostratigraphy of Mongolia. Joint Soviet-Mongolian Paleontological Expedition, Transactions, 3. Nauka Press, Moscow. (In Russian)

Baumel, J.J., King, A.S., Breazile, J.E., Evans, H.E. and Vanden Berge, J.C. 1993. Handbook of Avian Anatomy: Nomina Anatomica Avium (second edition). Nuttall Ornithological Club, Cambridge.

Biewener, A.A. 2008. Tendons and ligaments: structure, mechanical behavior and biological function, p. 269-284. In Fratzl, P. (ed.), Collagen: Structure and Mechanics. Springer Science+Business Media, LLC, New York.

Birchard, G.F. and Deeming, D.C. 2009. Avian eggshell thickness: scaling and maximum body mass in birds. Journal of Zoology, 279:91-101.

Bonaparte, J.F., and Powell, J.E. 1980. A continental assemblage of tetrapods from the Upper Cretaceous beds of El Brete, northwestern Argentina (Sauropoda-Coelurosauria-Carnosauria-Aves). Mémoires de la Société Géologique de France, Nouvelle Série, 139:19-28.

Bonde, N., and Christiansen, P. 2003. The detailed anatomy of Rhamphorynchus: axial pneumaticity and its implications, p. 217-232. In Buffetaut, E. and Mazin, J.-M. (eds.), Evolution and Palaeobiology of Pterosaurs. London: Geological Society.

Borissiak, A.A. 1915. Ob indrikoterii (Indricotherium n.g.). Geologiskie Vestnik, 1:131-134. (In Russian)

Borsuk-Bialynicka, M. 1977. A new camarasaurid sauropod Opisthocoelicaudia skarzynskii, gen. n., sp. n., from the Upper Cretaceous of Mongolia. Palaeontologia Polonica, 37:5-64.

Brisson, M.J. 1760. Ornithologie ou méthode contenant la division des oiseaux en ordres, sections, genres, especes \& leurs variétés. A laquelle on a joint une description exacte de chaque espece, avec les citations des auteurs qui en ont traité, les noms qu'ils leur ont donnés, ceux que leur ont donnés les différentes nations, \& les noms vulgaires. Ouvrage enrichi de figures en taille-douce. Tome V. J.B. Bauche, Paris.

Bryant, H.N., and Russell, A.P. 1992. The role of phylogenetic analysis in the inference of unpreserved attributes of extinct taxa. Philosophical Transactions: Biological Sciences, 337:405-418. 
Buffetaut, E., Grigorescu, D., and Csiki, Z. 2002a. A new giant pterosaur with a robust skull from the latest Cretaceous of Romania. Naturwissenschaften, 89:180-184.

Buffetaut, E., Suteethorn, V., Loeuff, J., Cuny, H., Tong, H. and Khansubha, S. 2002b. The first giant dinosaurs: a large sauropod from the Late Triassic of Thailand. Comptes Rendus Paleovol, 1:103-109.

Cai, Z. and Wei, F. 1994. Zhejiangopterus linhaiensis (Pterosauria) from the Upper Cretaceous of Linhai, Zhejiang, China. Vertebrata PalAsiatica, 32:181-194. (In Chinese)

Cameron, E.Z. and du Toit, J.T. 2007. Winning by a neck: tall giraffes avoid competing with shorter browsers. The American Naturalist, 169:130-135.

Carpenter, K. 2006. Biggest of the big: a critical re-evaluation of the mega-sauropod Amphicoelias fragillimus Cope, 1878. New Mexico Museum of Natural History and Science Bulletin, 36:131-137.

Chure, D., Britt, B.B., Whitlock, J.A. and Wilson, J.A. 2010. First complete sauropod dinosaur skull from the Cretaceous of the Americas and the evolution of sauropod dentition. Naturwissenschaften, 97(4): 379-391.

Clark, J.M., Norell, M.A. and Barsbold, R. 2001. Two new oviraptorids (Theropoda: Oviraptorosauria), Upper Cretaceous Djadokhta Formation, Ukhaa Tolgod, Mongolia. Journal of Vertebrate Paleontology, 21(2):209-213.

Clench, M.H. 1978. Tracheal elongation in birds-of-paradise. The Condor, 80:423-430.

Cobley, M.J. 2011. The flexibility and musculature of the ostrich neck: implications for the feeding ecology and reconstruction of the Sauropoda (Dinosauria: Saurischia). MSc thesis, University of Bristol, UK.

Cope, E.D. 1868. Remarks on a new enaliosaurian, Elasmosaurus platyurus. Proceedings of the Academy of Natural Sciences of Philadelphia, 1868:92-93.

Cope, E.D. 1870. On Elasmosaurus platyurus Cope. American Journal of Science, Series 2, 50(148):140-141.

Cope, E.D. 1877. On a gigantic saurian from the Dakota epoch of Colorado. Paleontological Bulletin, 25:5-10.

Cope, E.D. 1878. Geology and paleontology: a new species of Amphicoelias. The American Naturalist, 12:563-566.

Cranford, T.W. 1999. The sperm whale's nose: sexual selection on a grand scale? Marine Mammal Science, 15(4):1133-1157.

Crompton, A.W. and Charig, A.J. 1962. A new ornithischian from the Upper Triassic of South Africa. Nature, 196:1074-1077.

Currey, J.D. and Alexander, R. McN. 1985. The thickness of the walls of tubular bones. Journal of Zoology, 206:453-468.

Curry Rogers, K. and Forster, C.A. 2001. Last of the dinosaur titans: a new sauropod from Madagascar. Nature, 412:530-534.

Daudin, F.M. 1801. Histoire Naturelle, Generale et Particuliere des Reptiles, Volume 1. F. Dufart, Paris.

Deeming, D.C. and Birchard, G.F. 2009. Why were extinct gigantic birds so small? Avian Biology Research 1(4):187-194.

D’Emic, M.D. and Foreman, B.Z. 2012. The beginning of the sauropod dinosaur hiatus in North America: insights from the Lower Cretaceous Cloverly Formation of Wyoming. Journal of 
Vertebrate Paleontology 32(4):883-902.

Depéret, C. 1896. Note sur les dinosauriens sauropodes \& théropodes du Cretace Superieur de Madagascar. Bulletin de la Société Geologique de France, 24:176-194.

Dong, Z. 1979. The Cretaceous dinosaurs of South China, p. 342-350. In Institute of Vertebrate Paleontology and Paleoanthropology and Nanjing Institute of Paleontology, (eds.), Mesozoic and Cenozoic Red Beds of South China: Selected Papers from the Cretaceous-Tertiary Workshop. Nanxiong: Science Press. (In Chinese)

Dzemski, G. and Christian, A. 2007. Flexibility along the neck of the ostrich (Struthio camelus) and consequences for the reconstruction of dinosaurs with extreme neck length. Journal of Morphology, 268:701-714.

Evans, M. 1993. An investigation into the neck flexibility of two plesiosauroid plesiosaurs: Cryptoclidus eurymerus and Muraenosaurus leedsii. Unpublished MSc Thesis, University College London, London, UK.

Forster-Cooper, C. 1911. Paraceratherium bugtiense, a new genus of Rhinocerotidae from the Bugti Hills of Baluchistan, preliminary notice. Annals and Magazine of Natural History, 8:711-716.

Forster-Cooper, C. 1913. Correction of generic name [Thaumastotherium to Baluchitherium]. Annals and Magazine of Natural History, 12:504.

Frey, E. and Martill, D.M. 1996. A reappraisal of Arambourgiania (Pterosauria, Pterodactyloidea): one of the world's largest flying animals. Neues Jahrbuch für Geologie und Paläontologie, Abhandlungen, 199:221-247.

Frith, C.B. 1994. Adaptive significance of tracheal elongation in manucodes (Paradisaeidae). The Condor, 96:552-555.

Galis, F. 1999. Why do almost all mammals have seven cervical vertebrae? Developmental constraints, Hox genes, and cancer. Journal of Experimental Zoology (Mol Dev Evol), 285:19-26.

Galis, F. and Metz, J.A.J. 2003. Anti-cancer selection as a source of developmental and evolutionary constraints. BioEssays, 25:1035-1039.

Galton, P.M. 1978. Fabrosauridae, the basal family of ornithischian dinosaurs (Reptilia: Ornithischia). Paläontologische Zeitschrift, 52:138-159.

Galton, P.M. and Upchurch, P. 2004. Prosauropoda, p. 232-258. In Weishampel, D.B., Dodson, P. and Osmólska, H. (eds.), The Dinosauria, second edition. University of California Press, Berkeley.

Gauthier, J.A. 1986. Saurischian monophyly and the origin of birds. California Academy of Sciences Memoir, 8:1-55.Gilmore, C.W. 1936. Osteology of Apatosaurus, with special reference to specimens in the Carnegie Museum. Memoirs of the Carnegie Museum, 11:175-298.

Gomani, E.M. 2005. Sauropod dinosaurs from the Early Cretaceous of Malawi, Africa. Palaeontologia Electronica, 8.1.27A:1-37, 6.9MB; http://palaeo-electronica.org/2005 1/gomani27/issue1 05.htm

Gosho, M.E., Rice, D.W. and Breiwick, J.M. 1984. The sperm whale, Physeter macrocephalus. Marine Fisheries Review, 46(4):54-56.

Granger, W. and Gregory, W.K. 1935. A revised restoration of the skeleton of Baluchitherium, gigantic fossil rhinoceros of Central Asia. American Museum Novitates, 787:1-3. 
Hatcher, J.B. 1901. Diplodocus (Marsh): its osteology, taxonomy and probable habits, with a restoration of the skeleton. Memoirs of the Carnegie Museum, 1:1-63 and plates I-XIII.

Henderson, M.D. and Peterson, J.E. 2006. An azhdarchid pterosaur cervical vertebra from the Hell Creek Formation (Maastrichtian) of southeastern Montana. Journal of Vertebrate Paleontology, 26(1):192-195.

Howse, S.C.B. 1986. On the cervical vertebrae of the Pterodactyloidea (Reptilia: Archosauria). Zoological Journal of the Linnean Society, 88:307-328.

Hutchinson, J.R. 2002. The evolution of hindlimb tendons and muscles on the line to crown-group birds. Comparative Biochemistry and Physiology, Part A, 133:1051-1086.

Hutchinson, J.R., Bates, K.T., Molnar, J., Allen, V. and Makovicky, P.J. 2011. A computational analysis of limb and body dimensions in Tyrannosaurus rex with implications for locomotion, ontogeny, and growth. PLoS ONE 6(10):e26037. doi:10.1371/journal.pone.0026037

Jacobs, L.L., Winkler, D.A., Downs, W.R. and Gomani, E.M. 1993. New material of an Early Cretaceous titanosaurid sauropod dinosaur from Malawi. Palaeontology, 36:523-534.

Jain, S.L. and Bandyopadhyay, S. 1997. New titanosaurid (Dinosauria: Sauropoda) from the Late Cretaceous of central India. Journal of Vertebrate Paleontology, 17:114-136.

Janensch, W. 1914. Übersicht über der Wirbeltierfauna der Tendaguru-Schichten nebst einer kurzen Charakterisierung der neu aufgefuhrten Arten von Sauropoden. Archiv fur Biontologie, 3:81-110.

Janensch, W. 1929. Die Wirbelsaule der Gattung Dicraeosaurus. Palaeontographica, Supplement 7, 2:35-133.

Janensch, W. 1947. Pneumatizitat bei Wirbeln von Sauropoden und anderen Saurischien. Palaeontographica, Supplement 7, 3:1-25.

Janensch, W. 1950. Die Wirbelsaule von Brachiosaurus brancai. Palaeontographica, Supplement 7, 3:27-93.

Jensen, J.A. 1985. Three new sauropod dinosaurs from the Upper Jurassic of Colorado. Great Basin Naturalist, 45:697-709.

Johnsgard, P.A. 1983. Cranes of the World. Croom Helm, London.

Klein, N., Christian, A. and Sander, P.M. 2012. Histology shows that elongated neck ribs in sauropod dinosaurs are ossified tendons. Biology Letters. doi:10.1098/rsbl.2012.0778

Ksepka, D.T. and Norell, M.A. 2006. Erketu ellisoni, a long-necked sauropod from Bor Guve (Dornogov Aimag, Mongolia). American Museum Novitates, 3508:1-16.

Kubo, T., Mitchell, M.T. and Henderson, D.M. 2012. Albertonectes vanderveldei, a new elasmosaur (Reptilia, Sauropterygia) from the Upper Cretaceous of Alberta, Journal of Vertebrate Paleontology, 32:(3): 557-572.

Landis, W.J. and Silver, F.H. 2002. The structure and function of normally mineralizing avian tendons. Comparative Biochemistry and Physiology Part A, 133:1135-1157.

Langer, M.C. 2004. Basal Saurischia, p. 25-46. In Weishampel, D.B., Dodson, P. and Osmólska, H. (eds.), The Dinosauria, second edition. University of California Press, Berkeley.

Langston, W., Jr. 1981. Pterosaurs. Scientific American, 244:92-102

Latham, J. 1790. Index ornithologicus, sive systema ornithologiae; complectens avium divisionem in classes, ordines, genera, species, ipsarumque varietates, adjectis synonymis, locis, descriptionibus, \&c. Leigh and Sotheby, London.

Lawson, DA. 1975. Could pterosaurs fly? Science, 188:676-677. 
Leidy, J. 1870. On the Elasmosaurus platyurus of Cope. American Journal of Science, Series 2, 49(147):392.

Linnaeus, C. 1758. Systema naturae per regnum tria naturae secundum classes, ordines, genera, species, cum characteribus, differentiis, synonimis, loci, Edition 10, Volume 1. Stockholm: Salvius.

Lull, R.S. 1911. Systematic Paleontology, Lower Cretaceous: Vertebrata. Maryland Geological Survey, Lower Cretaceous, 183-210 and plates XI-XX.

Maleev, E.A. 1954. New turtle-like reptile in Mongolia. Priroda, 3:106-108. (in Russian)

Mallison, H. 2011. Rearing giants: kinetic-dynamic modeling of sauropod bipedal and tripodal poses, p. 237-250. In Klein, N., Remes, K., Gee, C.T. and Sander, M.P. (eds.), Biology of the Sauropod Dinosaurs. Indiana University Press, Bloomington, Indiana.

Marsh, O.C. 1877. Notice of new dinosaurian reptiles from the Jurassic formation. American Journal of Science, Series 3, 14:514-516.

Marsh, O.C. 1879a. Notice of new Jurassic reptiles. American Journal of Science, Series 3, 18:501-505.

Marsh, O.C. 1879b. Principal characters of American Jurassic dinosaurs, Part II. American Journal of Science, Series 3, 17:86-92.

Marsh, O.C. 1890. Description of new dinosaurian reptiles. American Journal of Science, Series 3, 39:81-86.

Martill, D.M., Frey, E., Sadaqah, R.M. And Khoury, H.N. 1998. Discovery of the holotype of the giant pterosaur Titanopteryx philadephiae Arambourg, 1959 and the status of Arambourgiania and Quetzalcoatlus. Neues Jahrbuch für Geologie und Paläontologie, Abhandlungen, 207:57-76.

Martin, J. 1987. Mobility and feeding of Cetiosaurus (saurischia, sauropoda) - why the long neck?, p. 154-159. In Currie, P.J. and Koster, E.H. (eds.), Fourth Symposium on Mesozoic Terrestrial Ecosystems, Short Papers. Boxtree Books, Drumheller.

Martin, V. 1994. Baby sauropods from the Sao Khua Formation (Lower Cretaceous) in Northeastern Thailand. Gaia, 10:147-153.

Martin, J., Martin-Rolland, V. and Frey, E. 1998. Not cranes or masts, but beams: the biomechanics of sauropod necks. Oryctos, 1:113-120.

McIntosh, J.S. 1995. Remarks on the North American sauropod Apatosaurus Marsh, p. 119-123. In Sun, A. and Wang, Y. (eds.), Sixth Symposium on Mesozoic Terrestrial Ecosystems and Biota. China Ocean Press, Beijing.

McIntosh, J.S. 2005. The genus Barosaurus Marsh (Sauropoda, Diplodocidae), p. 38-77. In Tidwell, V. and Carpenter, K. (eds.), Thunder Lizards: the Sauropodomorph Dinosaurs. Indiana University Press, Bloomington.

McIntosh, J.S., Miles, C.A., Cloward, K.C. and Parker, J.R. 1996a. A new nearly complete skeleton of Camarasaurus. Bulletin of Gunma Museum of Natural History, 1:1-87.

McIntosh, J.S., Miller, W.E., Stadtman, K.L. and Gillette, D.G. 1996b. The osteology of Camarasaurus lewisi (Jensen, 1988). Brigham Young University Geology Studies, 41:73-116.

Meyer, H.v. 1846. Pterodactylus (Rhamphorhynchus) gemmingi aus dem Kalkschiefer von Solenhofen. Palaeontographica, 1:1-20.

Mivart, St. George. 1874. On the axial skeleton of the ostrich (Struthio camelus). Transactions of the Zoological Society of London, 8(7):385-451. 
Murray, P.F. and Vickers-Rich, P. 2004. Magnificent Mihirungs. Indiana University Press, Bloomington.

Naish D. 2008. Invading the postzyg, downloaded 17 June 2012. Sauropod Vertebra Picture of the Week. http://svpow.com/2008/03/30/invading-the-postzyg/

Naish, D. and Martill, D.M. 2001. Saurischian dinosaurs 1: Sauropods, p. 185-241. In Martill, D.M. and Naish, D. (eds.). Dinosaurs of the Isle of Wight. The Palaeontological Association, London.

Nishiwaki, M., Ohsumi, S. and Maeda, Y. 1963. Change of form in the sperm whale accompanied with growth. Scientific Reports of the Whales Research Institute, Tokyo, 17:1-17.

Nosotti, S. 2007. Tanystropheus longobardicus (Reptilia, Protorosauria): reinterpretations of the anatomy based on new specimens from the Middle Triassic of Besano (Lombardy, Northern Italy). Memorie della Società Italiana di Scienze Naturali e del Museo Civico di Storia Naturale di Milano 35(3):1-88.

Novas, F.E., Salgado, L., Calvo, J. and Agnolin, F. 2005. Giant titanosaur (Dinosauria, Sauropoda) from the Late Cretaceous of Patagonia. Revista del Museo Argentino dei Ciencias Naturales, Nuevo Serie, 7:37-41.

O'Connor, P.M. 2007. The postcranial axial skeleton of Majungasaurus crenatissimus (Theropoda: Abelisauridae) from the Late Cretaceous of Madagascar, p. 127-162. In Sampson, S.D. and Krause, D.W. (eds.). Majungasaurus crenatissimus (Theropoda: Abelisauridae) from the Late Cretaceous of Madagascar. Society of Vertebrate Paleontology Memoir 8.

Osborn, H.F. 1898. Additional characters of the great herbivorous dinosaur Camarasaurus. Bulletin of the American Museum of Natural History, 10:219-233.

Osborn, H.F. 1905. Tyrannosaurus and other Cretaceous carnivorous dinosaurs. Bulletin of the American Museum of Natural History, 21:259-265.

Osborn, H.F. and Mook, C.C. 1921. Camarasaurus, Amphicoelias and other sauropods of Cope. Memoirs of the American Museum of Natural History, New Series, 3:247-387.

Ostrom, J.H. 1969a. A new theropod dinosaur from the Lower Cretaceous of Montana. Postilla, 128:1-17.

Ostrom, J.H. 1969b. Osteology of Deinonychus antirrhopus, an unusual theropod from the Lower Cretaceous of Montana. Bulletin of the Peabody Museum of Natural History, 30:1-165.

Ostrom, J.H. and McIntosh, J.S. 1966. Marsh's Dinosaurs: the Collections from Como Bluff. Yale University Press, New Haven.

Parrish, J.M. 2006. The origins of high browsing and the effects of phylogeny and scaling on neck length in sauropodomorphs, p. 201-224. In Carrano, M.T., Gaudin, T.J., Blob, R.W. and Wible, J.R. (eds.), Amniote Paleobiology. University of Chicago Press, Chicago.

Paul, G.S. 1988. The brachiosaur giants of the Morrison and Tendaguru with a description of a new subgenus, Giraffatitan, and a comparison of the world's largest dinosaurs. Hunteria, 2:1-14.

Paul, G.S. 1997. Dinosaur models: the good, the bad, and using them to estimate the mass of dinosaurs, p. 129-154. In Wohlberg, D.L., Stump, E. and Rosenberg, G.D. (eds.), Dinofest International: Proceedings of a Symposium Held at Arizona State University. Academy of Natural Sciences, Philadelphia.

Pereda-Suberbiola, X., Bardet, N., Jouve, S., Iarochène, M., Bouya, B. and Amaghzaz, M. 2003. 
A new azhdarchid pterosaur from the Late Cretaceous phosphates of Morocco. Geological Society, London, Special Publications, 217:79-90. doi: 10.1144/GSL.SP.2003.217.01.08

Powell, J.E. 1992. Osteología de Saltasaurus loricatus (Sauropoda-Titanosauridae) del Cretácico Superior del Noroeste Argentino, p. 165-230. In Sanz, J.L. and Buscalioni, A.D. (eds.), Los Dinosaurios y su Entorno Biotico. Actas del Segundo Curso de Paleontologia en Cuenca. Ayuntamiento de Cuenca, Instituto Juan de Valdés, Cuenca, Spain.

Reid, R.E.H. 1996. Bone histology of the Cleveland-Lloyd dinosaurs and of dinosaurs in general, Part 1: Introduction: introduction to bony tissues. Brigham Young University Geology Studies, 41:25-72.

Riggs, E.S. 1903. Structure and relationships of opisthocoelian dinosaurs. Part I, Apatosaurus Marsh. Field Columbian Museum, Geological Series, 2:165-196.

Russell, D.A. and Zheng, Z. 1993. A large mamenchisaurid from the Junggar Basin, Xinjiang, People's Republic of China. Canadian Journal of Earth Sciences, 30:2082-2095.

Sachs, S. 2005. Redescription of Elasmosaurus platyurus Cope 1868 (Plesiosauria: Elasmosauridae) from the Upper Cretaceous (Lower Campanian) of Kansas, U.S.A. Paludicola, 5:92-106.

Santa Luca, A.P. 1980. The postcranial skeleton of Heterodontosaurus tucki (Reptilia, Ornithischia) from the Stormberg of South Africa. Annals of the South African Museum, 79:159-211.

Schwarz, D. and Fritsch, G. 2006. Pneumatic structures in the cervical vertebrae of the Late Jurassic Tendaguru sauropods Brachiosaurus brancai and Dicraeosaurus. Eclogae Geologicae Helvetiae, 99:65-78.

Schwarz, D., Frey, E. and Meyer, C.A. 2007. Pneumaticity and soft-tissue reconstructions in the neck of diplodocid and dicraeosaurid sauropods. Acta Palaeontologica Polonica, 52:167-188.

Seeley, H.G. 1874. On Muraenosaurus leedsii, a plesosaurian from the Oxford Clay. Quarterly Journal of the Geological Society, London, 30:197-208.

Seeley, H.G. 1892. The nature of the shoulder girdle and clavicular arch in the Sauropterygia. Proceedings of the Royal Society, London, 51:119-151.

Seki, Y., Schneider, M.S. and Meyers, M.A. 2005. Structure and mechanical behavior of a toucan beak. Acta Materialia, 53:5281-5296.

Senter, P. 2006. Necks for sex: sexual selection as an explanation for sauropod dinosaur neck elongation. Journal of Zoology, 271:45-53.

Sereno, P.C. 1991a. Basal archosaurs: phylogenetic relationships and functional implications. Society of Vertebrate Paleontology Memoir, 2:1-53.

Sereno, P.C. 1991b. Lesothosaurus, 'fabrosaurids,' and the early evolution of Ornithischia. Journal of Vertebrate Paleontology, 11:168-197.

Simmons, R.E. and Scheepers, L. 1996. Winning by a neck: sexual selection in the evolution of giraffe. American Naturalist, 148:771-786.

Spector, W.S. (ed.) 1956. Handbook of biological data. W.B. Saunders, Philadelphia.

Tambussi, C.P., de Mendoza, R., Degrange, F.J. and Picasso, M.B. 2012. Flexibility along the neck of the Neogene terror bird Andalgalornis steulleti (Aves Phorusrhacidae). PLoS ONE 7(5): e37701. doi:10.1371/journal.pone.0037701

Taylor, M.P. 2009. A re-evaluation of Brachiosaurus altithorax Riggs 1903 (Dinosauria, Sauropoda) and its generic separation from Giraffatitan brancai (Janensch 1914). Journal of 
Vertebrate Paleontology, 29:787-806.

Taylor, M.P. and Naish, D. 2007. An unusual new neosauropod dinosaur from the Lower Cretaceous Hastings Beds Group of East Sussex, England. Palaeontology, 50:1547-1564.

Taylor, M.P., Wedel, M.J. and Naish, D. 2009. Head and neck posture in sauropod dinosaurs inferred from extant animals. Acta Palaeontologica Polonica, 54(2):213-220.

Taylor, M.P., Hone, D.W.E., Wedel, M.J. and Naish, D. 2011. The long necks of sauropods did not evolve primarily through sexual selection. Journal of Zoology, 285(2):150-161. doi:10.1111/j.1469-7998.2011.00824.x

Toon, A. and Toon, S.B. 2003. Okapis and giraffes, p. 299-409. In Hutchins, M., Kleiman, D., Geist, V. and McDade, M. (eds.), Grzimek's Animal Life Encyclopedia, Vol 15: Mammals IV (second edition). Gale Group, Farmington Hills, Michigan.

Tschanz K. 1988. Allometry and heterochrony in the growth of the neck of Triassic prolacertiform reptiles. Palaeontology 31(4):997-1011.

Tsuihiji, T. 2004. The ligament system in the neck of Rhea americana and its implication for the bifurcated neural spines of sauropod dinosaurs. Journal of Vertebrate Paleontology, 24:165-172.

Tsuihiji, T. 2005. Homologies of the transversospinalis muscles in the anterior presacral region of Sauria (crown Diapsida). Journal of Morphology, 263:151-178.

Upchurch, P., Tomida, Y. and Barrett, P.M. 2005. A new specimen of Apatosaurus ajax (Sauropoda: Diplodocidae) from the Morrison Formation (Upper Jurassic) of Wyoming, USA. National Science Museum Monographs, 26:1-110.

van der Leeuw, A.H.J., Bout, R.G. and Zweers, G.A. 2001. Evolutionary morphology of the neck system in ratites, fowl, and waterfowl. Netherlands Journal of Zoology, 51(2):243-262.

Wedel, M.J. 2003. Vertebral pneumaticity, air sacs, and the physiology of sauropod dinosaurs. Paleobiology, 29:243-255.

Wedel, M.J. 2005. Postcranial skeletal pneumaticity in sauropods and its implications for mass estimates, p. 201-228. In Wilson, J.A. and Curry Rogers, K. (eds.), The Sauropods: Evolution and Paleobiology. University of California Press, Berkeley.

Wedel, M.J. 2006a. Pneumaticity, neck length, and body size in sauropods. Journal of Vertebrate Paleontology, 26(Supplement to Number 3):137A.

Wedel, M.J. 2006b. Origin of postcranial skeletal pneumaticity in dinosaurs. Integrative Zoology, 2:80-85.

Wedel, M.J. 2007a. Postcranial pneumaticity in dinosaurs and the origin of the avian lung. Unpublished PhD Thesis, University of California, Berkeley, California, USA.

Wedel, M.J. 2007b. What pneumaticity tells us about 'prosauropods', and vice versa, p. 207-222. In Barrett, P.M. and Batten, D.J. (eds.), Evolution and Palaeobiology of Early Sauropodomorph Dinosaurs. Special Papers in Palaeontology, 77.

Wedel, M.J. 2009. Evidence for bird-like air sacs in saurischian dinosaurs. Journal of Experimental Zoology, Part A, 311:611-828.

Wedel, M.J. and Sanders RK. 2002. Osteological correlates of cervical musculature in Aves and Sauropoda (Dinosauria: Saurischia), with comments on the cervical ribs of Apatosaurus. PaleoBios, 22(3):1-6.

Wedel, M.J., Cifelli, R.L. and Sanders, R.K. 2000a. Sauroposeidon proteles, a new sauropod from the Early Cretaceous of Oklahoma. Journal of Vertebrate Paleontology, 20:109-114. 
Wedel, M.J., Cifelli, R.L. and Sanders, R.K. 2000b. Osteology, paleobiology, and relationships of the sauropod dinosaur Sauroposeidon. Acta Palaeontologica Polonica, 45:343-388.

Wilson, J.A. and Sereno, P.C. 1998. Early evolution and higher-level phylogeny of sauropod dinosaurs. Society of Vertebrate Paleontology Memoir, 5:1-68.

Wilson, J.A. and Upchurch, P. 2003. A revision of Titanosaurus Lydekker (Dinosauria Sauropoda), the first dinosaur genus with a 'Gondwanan' distribution. Journal of Systematic Palaeontology, 1:125-160.

Wiman, C. 1929. Die Kreide-Dinosaurier aus Shantung. Palaeontologia Sinica, Series C, 6:1-67.

Witmer, L.M. 1995. The extant phylogenetic bracket and the importance of reconstructing soft tissues in fossils, p. 19-33. In Thomason, J.J. (ed.), Functional Morphology in Vertebrate Paleontology. Cambridge University Press, Cambridge.

Witton, M.P. and Habib, M.B. 2010. On the size and flight diversity of giant pterosaurs, the use of birds as pterosaur analogues and comments on pterosaur flightlessness. PLoS ONE, 5(10):e13982. doi:10.1371/journal.pone.0013982

Witton, M.P. and Naish, D. 2008. A reappraisal of azhdarchid pterosaur functional morphology and paleoecology. PLoS ONE, 3:e2271. doi:10.1371/journal.pone.000227

Worthy, T.H. and Holdaway, R.N. 2002. The Lost World of the Moa. Indiana University Press, Bloomington.

Xu, X., Tan, Q., Wang, J., Zhao, X. and Tan, L. 2007. A gigantic bird-like dinosaur from the Late Cretaceous of China. Nature, 447:844-847.

Young. C.-C.. 1939. On a new Sauropoda, with notes on other fragmentary reptiles from Szechuan. Bulletin of the Geological Society of China, 19:279-315.

Young, C.-C. 1954. On a new sauropod from Yiping, Szechuan, China. Acta Scientia Sinica, 3:491-504.

Young, C.-C. and Zhao, X. 1972. Mamenchisaurus hochuanensis sp. nov. Institute of Vertebrate Paleontology and Paleoanthropology Monograph, Series I 8:1-30. (In Chinese)

Zhang, X.-H., Xu, X., Zhao, X.-J., Sereno, P., Kwang, X.-W. and Tan, L. 2001. A long-necked therizinosauroid dinosaur from the Upper Cretaceous Iren Dabasu Formation of Nei Mongol, People’s Republic of China. Vertebrata PalAsiatica, 39(4):282-290.

Zweers, G.A., Vanden Berge, J.C. and Koppendraier, R. 1987. Avian cranio-cervical systems. Part I: Anatomy of the cervical column in the chicken (Gallus gallus L.). Acta Morphologica Neerlando-Scandinavica, 25:131-155.

\section{Museum Abbreviations}

BYU, Earth Sciences Museum, Brigham Young University, Provo, Utah (USA)

CM, Carnegie Museum of Natural History, Pittsburgh, Pennsylvania (USA)MfN, Museum für Naturkunde Berlin, Berlin (Germany) (collection numbers for fossil reptiles: MB.R.\#\#\#\#)

FMNH, Field Museum of Natural History, Chicago, Illinois (USA)

IGM, Geological Institute of the Mongolian Academy of Sciences, Ulaan Baatar (Mongolia)

ISI, Geology Museum, Indian Statistical Institute, Calcutta (India)

MAL, Malawi Department of Antiquities Collection, Lilongwe and Nguludi (Malawi) 
| MCZ, Museum of Comparative Zoology, Harvard University, Cambridge, Massachusetts (USA) MIWG, Dinosaur Isle, Sandown, Isle of Wight (UK)

OMNH, Oklahoma Museum of Natural History, Norman, Oklahoma (USA)

| PIMUZ, University of Zurich Paleontology Museum, Zurich (Switzerland)

| PMU, Palaeontological Museum, Uppsala (Sweden)

| $\underline{\text { UA, Université d'Antananarivo, Antananarivo (Madagascar) }}$

| UJF, University of Jordan Department of Geology Collections, Amman (Jordan)

WDC, Wyoming Dinosaur Center, Thermopolis, Wyoming (USA)

| ZMNH, Zhejiang Museum of Natural History, Hangzhou (China) 


\section{Table $\mathbf{1}_{\text {(on next page) }}$}

Neck statistics of some sauropods, chosen because of unusually long, short or complete necks. 
Table 1. Neck statistics of some sauropods, chosen because of unusually long, short or complete necks.

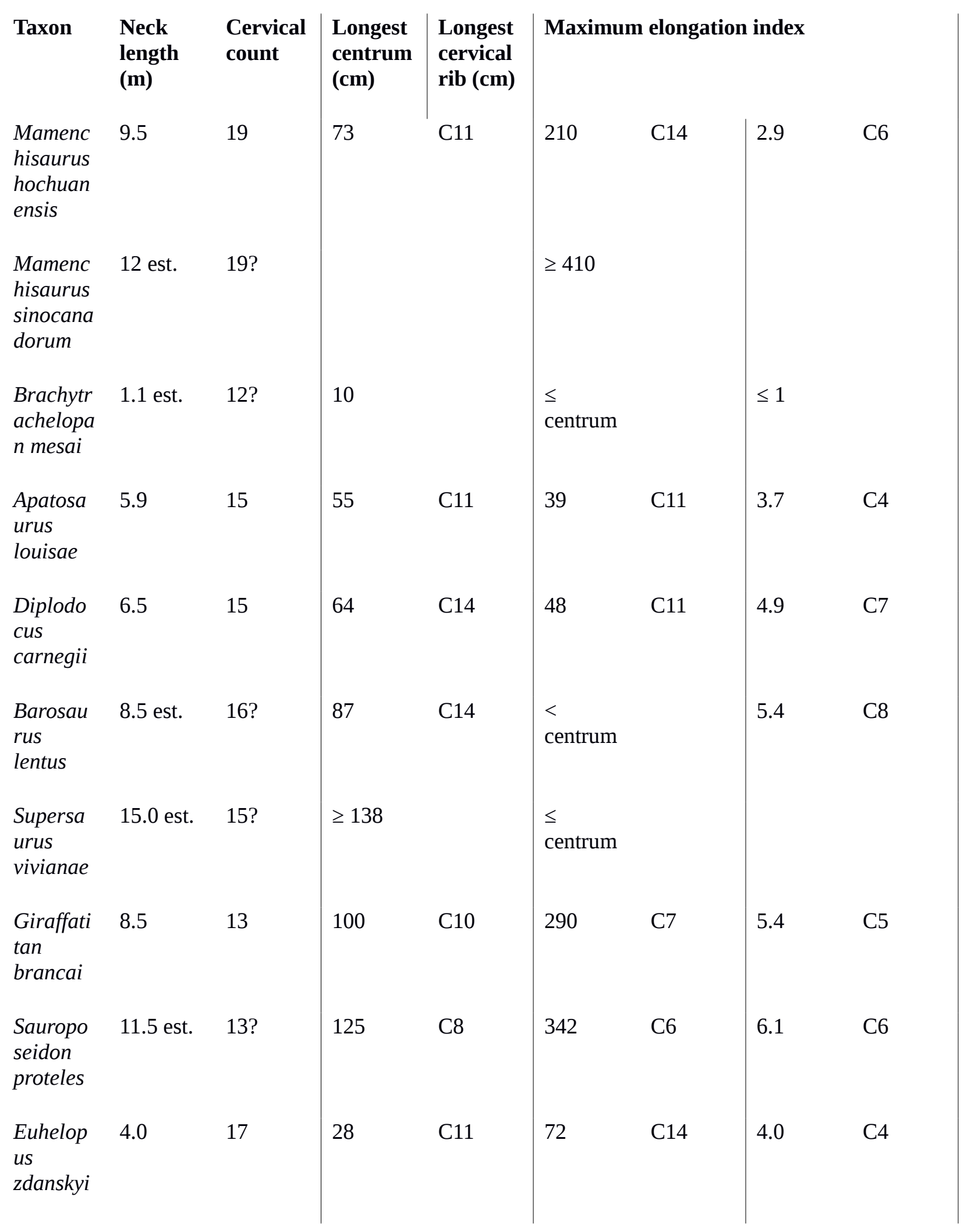




\section{Table $2_{\text {(on next page) }}$}

Air Space Proportion (ASP) of sections through sauropod vertebrae.

Air Space Proportion (ASP) of sections through sauropod vertebrae. Measurements are taken from CT sections, photographs, and published images. Sections are transverse unless otherwise noted. Although this dataset is almost three times as large as that reported by Wedel (2005), the mean is the about same, 0.61 compared to 0.60. Abbreviations: C, cervical; Cd, caudal; D, dorsal; P, presacral. 
Table 2. Air Space Proportion (ASP) of sections through sauropod vertebrae. Measurements are taken from CT sections, photographs, and published images. Sections are transverse unless otherwise noted. Although this dataset is almost three times as large as that reported by Wedel (2005), the mean is the about same, 0.61 compared to 0.60. Abbreviations: C, cervical; Cd, caudal; D, dorsal; P, presacral.

\begin{tabular}{|c|c|c|c|c|}
\hline Taxon & $\begin{array}{l}\text { Regio } \\
\text { n }\end{array}$ & & ASP & Source \\
\hline \multirow[t]{13}{*}{ Apatosaurus } & $\mathrm{C}$ & condyle & 0.69 & OMNH 01094 \\
\hline & & mid-centrum & 0.52 & “ \\
\hline & & posterior centrum & 0.73 & “ \\
\hline & & cotyle & 0.32 & “ \\
\hline & $\mathrm{C}$ & condyle & 0.63 & OMNH 01340 \\
\hline & & mid-centrum & 0.69 & “ \\
\hline & & cotyle & 0.49 & “ \\
\hline & $\mathrm{C}$ & condyle & 0.52 & CM 555 C6 \\
\hline & & mid-centrum & 0.75 & “ \\
\hline & & posterior centrum & 0.59 & “ \\
\hline & & cotyle & 0.34 & “ \\
\hline & $\mathrm{C}$ & parapophysis & 0.6 & BYU 11998 \\
\hline & $\mathrm{C}$ & cotyle & 0.7 & BYU 11889 \\
\hline \multirow[t]{3}{*}{ Brachiosaurus } & $\mathrm{C}$ & condyle & 0.55 & BYU 12866 \\
\hline & & mid-centrum & 0.67 & “ \\
\hline & & posterior centrum & 0.81 & “ \\
\hline \multirow[t]{4}{*}{ Brachiosauridae } & $\mathrm{C}$ & mid-centrum & 0.89 & MIWG 7306 \\
\hline & $\mathrm{P}$ & & 0.65 & Naish and Martill (2001, plate 32) \\
\hline & $\mathrm{P}$ & & 0.85 & Naish and Martill (2001, plate 33) \\
\hline & $\mathrm{P}$ & & 0.85 & MIWG uncatalogued \\
\hline \multirow[t]{9}{*}{ Camarasaurus } & $\mathrm{C}$ & condyle & 0.51 & OMNH 01109 \\
\hline & & mid-centrum & 0.68 & “ \\
\hline & & cotyle & 0.54 & “ \\
\hline & $\mathrm{C}$ & condyle & 0.49 & OMNH 01313 \\
\hline & & mid-centrum & 0.52 & “ \\
\hline & & cotyle & 0.5 & “ \\
\hline & $\mathrm{D}$ & mid-centrum & 0.58 & $\begin{array}{l}\text { Ostrom and McIntosh (1966, plate } \\
\text { 23) }\end{array}$ \\
\hline & $\mathrm{D}$ & mid-centrum & 0.63 & $\begin{array}{l}\text { Ostrom and McIntosh (1966, plate } \\
\text { 23) }\end{array}$ \\
\hline & $\mathrm{D}$ & mid-centrum & 0.71 & $\begin{array}{l}\text { Ostrom and McIntosh (1966, plate } \\
\text { 23) }\end{array}$ \\
\hline $\begin{array}{l}\text { Chondrosteosauru } \\
\text { S }\end{array}$ & $\mathrm{P}$ & centrum (horiz.) & 0.7 & Naish and Martill (2001, figure 8.5) \\
\hline \multirow[t]{3}{*}{ Diplodocus } & $\mathrm{C}$ & condyle & 0.56 & BYU 12613 \\
\hline & & mid-centrum & 0.54 & “ \\
\hline & & posterior centrum & 0.66 & “ \\
\hline \multirow[t]{3}{*}{ Giraffatitan } & $\mathrm{C}$ & condyle & 0.73 & Janensch (1950, figure 70) \\
\hline & $\mathrm{C}$ & condyle (sagittal) & 0.57 & Janensch (1947, figure 4) \\
\hline & $\mathrm{D}$ & mid-centrum & 0.59 & Janensch (1947, figure 2) \\
\hline Haplocanthosauru & $\mathrm{C}$ & condyle & 0.39 & CM 879-7 \\
\hline
\end{tabular}


S

\begin{tabular}{|c|c|c|c|c|}
\hline & & mid-centrum & 0.56 & “ \\
\hline & & posterior centrum & 0.42 & “ \\
\hline & & cotyle & 0.28 & “ \\
\hline & $\mathrm{D}$ & mid-centrum & 0.36 & CM 572 \\
\hline Malawisaurus & $\mathrm{C}$ & condyle & 0.56 & MAL-280-1 \\
\hline & & mid-centrum & 0.62 & “ \\
\hline & $\mathrm{C}$ & condyle & 0.57 & MAL-280-4 \\
\hline & & mid-centrum & 0.56 & “ \\
\hline Phuwiangosaurus & $\mathrm{C}$ & mid-centrum & 0.55 & Martin (1994, figure 2) \\
\hline Pleurocoelus & $\mathrm{C}$ & mid-centrum & 0.55 & Lull (1911, plate 15) \\
\hline Saltasaurus & $\mathrm{D}$ & centrum (horiz.) & 0.62 & Powell (1992, figure 16) \\
\hline & & mid-centrum & 0.55 & “ \\
\hline & & $\begin{array}{l}\text { neural spine } \\
\text { (horiz.) }\end{array}$ & 0.82 & “ \\
\hline & $\mathrm{D}$ & prezygapophysis & 0.78 & Powell (1992, figure 16) \\
\hline Sauroposeidon & $\mathrm{C}$ & prezyg. ramus & 0.89 & OMNH 53062 \\
\hline & & postzygapophysis & 0.74 & “ \\
\hline & & anterior centrum & 0.75 & “ \\
\hline Supersaurus & $\mathrm{C}$ & mid-centrum & 0.64 & WDC-DMJ021 \\
\hline Tornieria & $\mathrm{C}$ & mid-centrum & 0.56 & Janensch (1947, figure 8) \\
\hline & $\mathrm{C}$ & posterior centrum & 0.77 & Janensch (1947, figure 3) \\
\hline & $\mathrm{D}$ & condyle (sagittal) & 0.78 & Janensch (1947, figure 9) \\
\hline & $\mathrm{Cd}$ & mid-centrum & 0.47 & Janensch (1947, figure 7$)$ \\
\hline Sauropoda indet. & $\mathrm{C}$ & mid-centrum & 0.54 & OMNH 01866 \\
\hline & $\mathrm{C}$ & posterior centrum & 0.46 & OMNH 01867 \\
\hline & $\mathrm{C}$ & mid-centrum & 0.55 & OMNH 01882 \\
\hline & $\begin{array}{l}\text { MEA } \\
\mathrm{N}\end{array}$ & & 0.61 & \\
\hline
\end{tabular}




\section{Table 3 (on next page)}

Neck-elongation features by taxon.

Neck-elongation features by taxon. 
Table 3. Neck-elongation features by taxon.

\begin{tabular}{|c|c|c|c|c|c|c|c|}
\hline & $\begin{array}{c}\text { Absolutely } \\
\text { large body } \\
\text { size }\end{array}$ & $\begin{array}{l}\text { Quadruped } \\
\text { al stance }\end{array}$ & Small head & $\begin{array}{l}\text { Numerous } \\
\text { cervical } \\
\text { vertebrae }\end{array}$ & $\begin{array}{c}\text { Elongate } \\
\text { cervical } \\
\text { vertebrae }\end{array}$ & $\begin{array}{l}\text { Air-sac } \\
\text { system }\end{array}$ & $\begin{array}{c}\text { Vertebral } \\
\text { pneumaticit } \\
y\end{array}$ \\
\hline \multicolumn{8}{|l|}{ Human } \\
\hline Giraffe & & $\checkmark$ & & & $v$ & & \\
\hline Ostrich & & & $v$ & $v$ & $v$ & $v$ & $v$ \\
\hline $\begin{array}{l}\text { Paraceratheriu } \\
m\end{array}$ & $\checkmark$ & $\checkmark$ & & & & & \\
\hline $\begin{array}{l}\text { Therizinosauru } \\
\text { s }\end{array}$ & $\checkmark$ & & $\checkmark$ & & & $v$ & $v$ \\
\hline Gigantoraptor & $v$ & & $\checkmark$ & & & $v$ & $\checkmark$ \\
\hline $\begin{array}{l}\text { Arambourgiani } \\
a\end{array}$ & & & & & $v$ & $\checkmark$ & $\checkmark$ \\
\hline Sauropods & $v$ & $v$ & $v$ & $v$ & $\checkmark$ & $\checkmark$ & $\checkmark$ \\
\hline
\end{tabular}




\section{Figure 1}

Necks of long-necked non-sauropods, to scale.

Necks of long-necked non-sauropods, to scale. The giraffe and Paraceratherium are the longest necked mammals; the ostrich is the longest necked extant bird; Therizinosaurus and Gigantoraptor are the largest representatives of two long-necked theropod clades; Arambourgiania is the longest necked pterosaur; and Tanystropheus has a uniquely long neck relative to torso length. Human head modified from Gray's Anatomy (1918 edition, fig. 602). Giraffe modified from photograph by Kevin Ryder (CC-BY, http://flic.kr/p/cRvCcQ ). Ostrich modified from photograph by “kei51” (CC-BY, http://flic.kr/p/cowoYW ). Paraceratherium modified from Osborn (1923, figure 1). Therizinosaurus modified from Nothronychus reconstruction by Scott Hartman. Gigantoraptor modified from Heyuannia reconstruction by Scott Hartman. Arambourgiania modified from Zhejiangopterus reconstruction by Witton and Naish (2008, figure 1). Tanystropheus modified from reconstruction by David Peters. Alternating blue and pink bars are $1 \mathrm{~m}$ tall. 


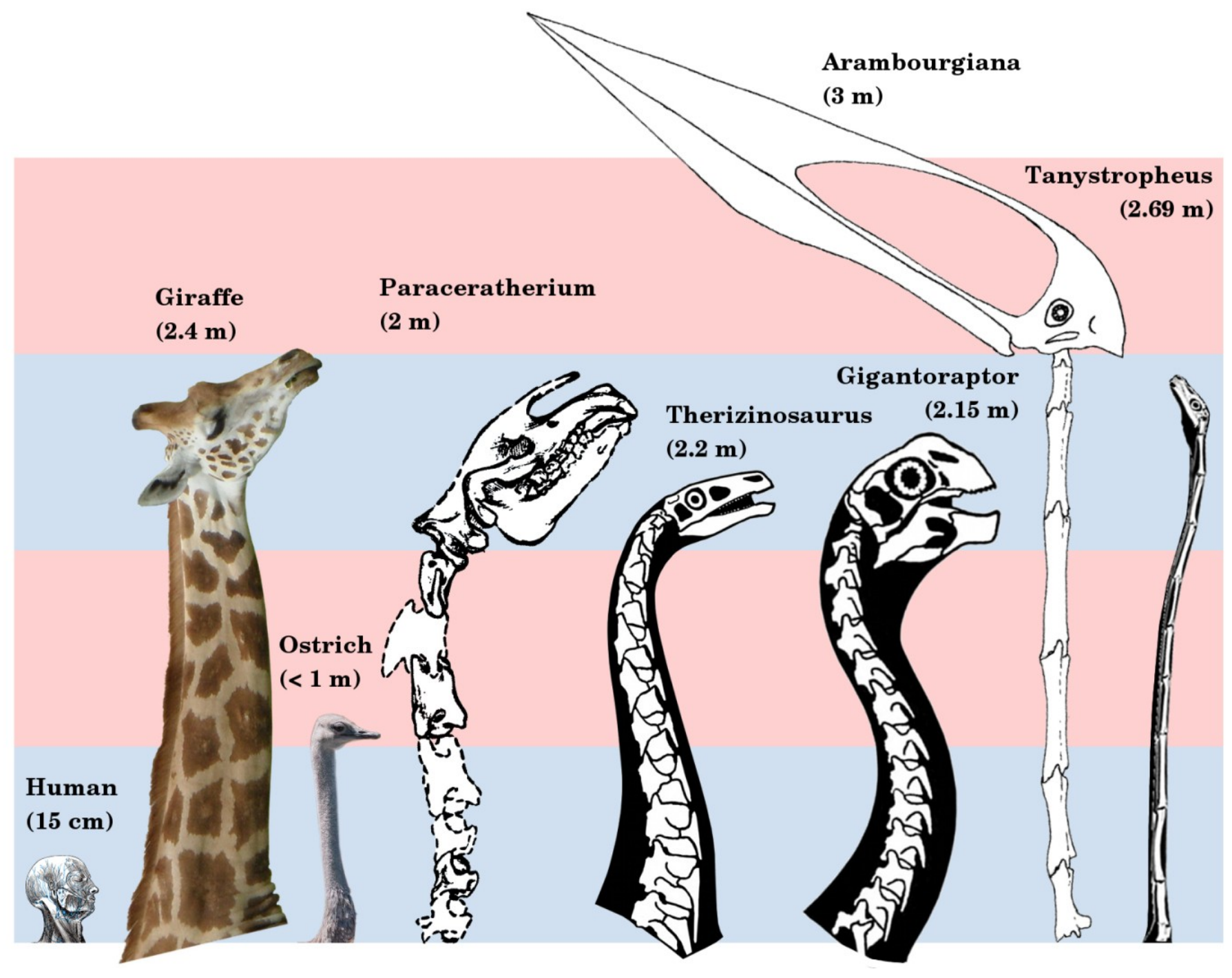




\section{Figure 2}

Full skeletal reconstructions of selected long-necked non-sauropods, to scale.

Full skeletal reconstructions of selected long-necked non-sauropods, to scale. 1, Paraceratherium. 2, Therizinosaurus. 3, Gigantoraptor. 4, Elasmosaurus. 5, Tanystropheus. Elasmosaurus modified from Cope (1870, plate II, figure 1). Other image sources as for Figure 1. Scale bar $=2 \mathrm{~m}$.

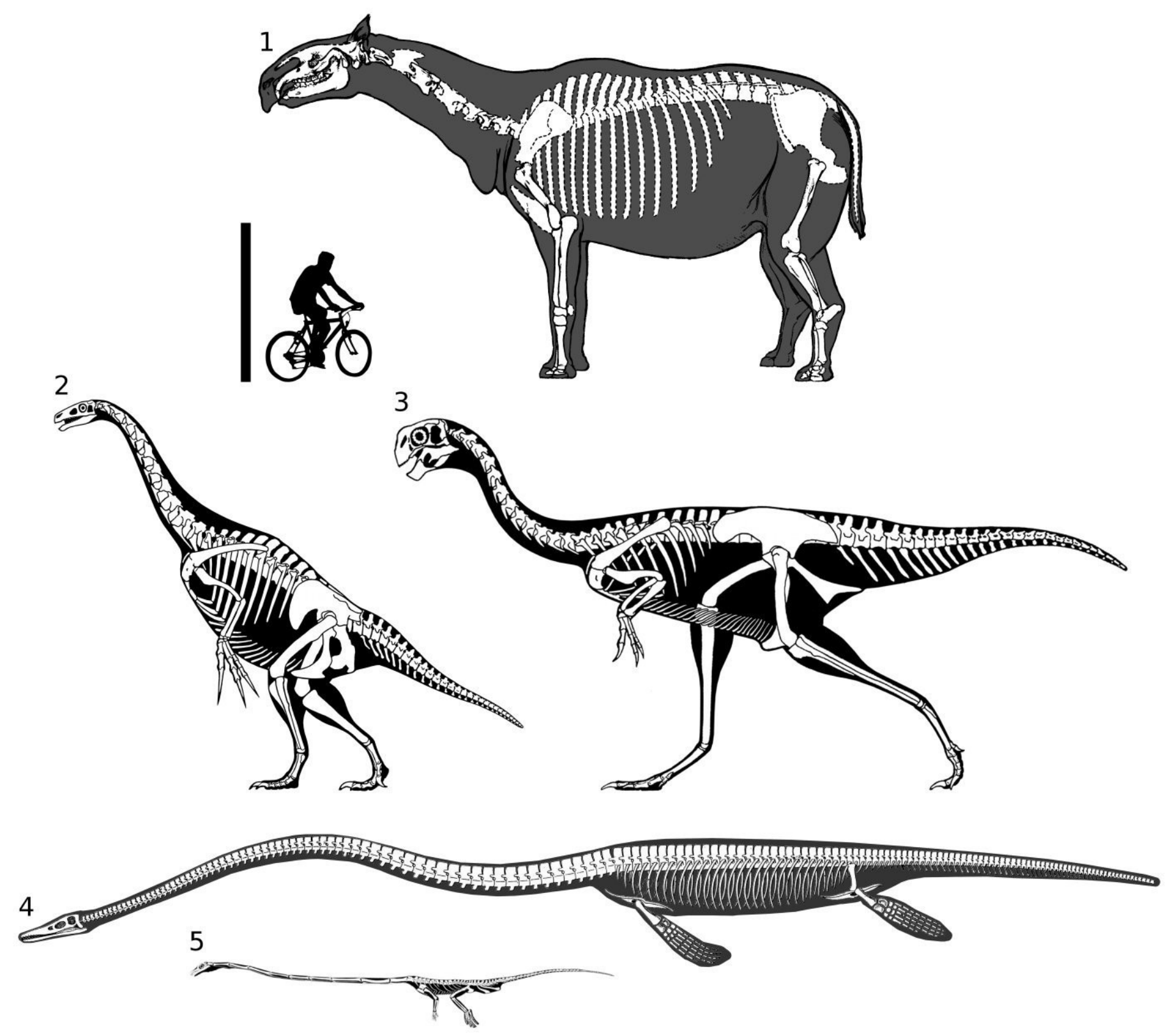




\section{Figure 3}

Necks of long-necked sauropods, to scale.

Necks of long-necked sauropods, to scale. Diplodocus, modified from elements in Hatcher (1901, plate 3), represents a "typical” long-necked sauropod, familiar from many mounted skeletons in museums. Puertasaurus, Sauroposeidon, Mamenchisaurus and Supersaurus modified from Scott Hartman's reconstructions of Futalognkosaurus, Cedarosaurus, Mamenchisaurus and Supersaurus respectively. Alternating pink and blue bars are one meter in width. Inset shows Figure 1 to the same scale.
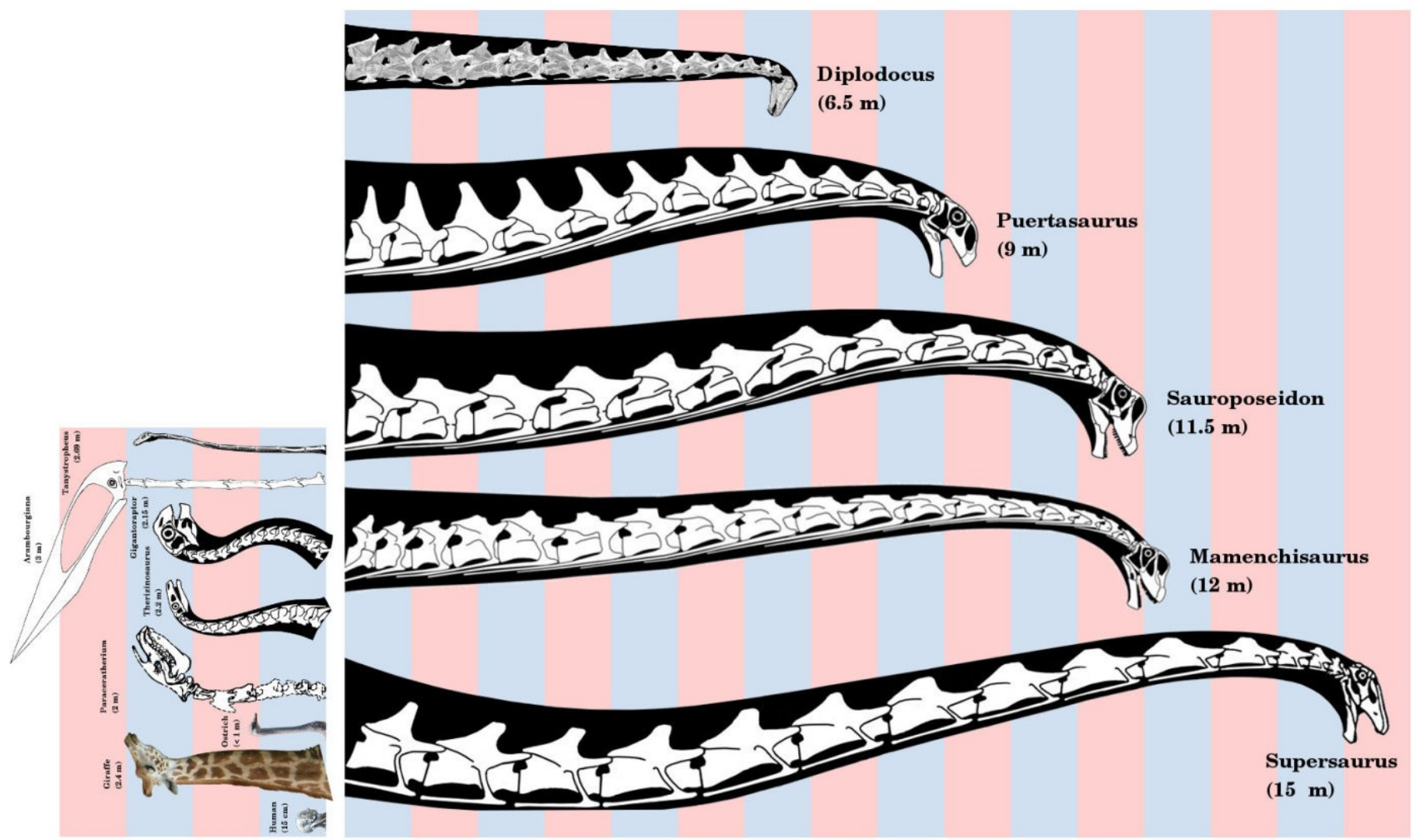


\section{Figure 4}

Extent of soft tissue on ostrich and sauropod necks.

Extent of soft tissue on ostrich and sauropod necks. 1, ostrich neck in cross section from Wedel (2003, figure 2). Bone is white, air-spaces are black, and soft tissue is grey. 2, hypothetical sauropod neck with similarly proportioned soft-tissue. (Diplodocus vertebra silhouette modified from Paul 1997, figure 4A). The extent of soft tissue depicted greatly exceeds that shown in any published life restoration of a sauropod, and is unrealistic. 3, More realistic sauropod neck. It is not that the soft-tissue is reduced but that the vertebra within is enlarged, and mass is reduced by extensive pneumaticity in both the bone and the soft-tissue.

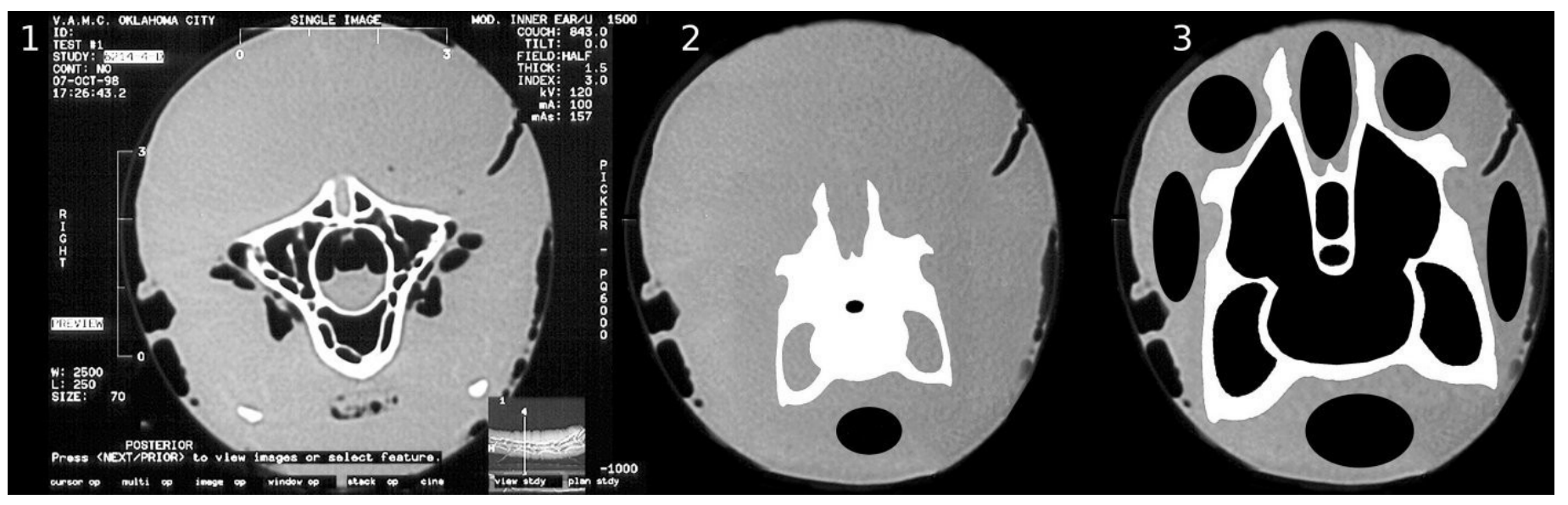




\section{Figure 5}

Simplified myology of that sauropod neck.

Simplified myology of that sauropod neck, in left lateral view, based primarily on homology with birds, modified from Wedel and Sanders (2002, figure 2). Dashed arrows indicate muscle passing medially behind bone. A, B. Muscles inserting on the epipophyses, shown in red. C, D, E. Muscles inserting on the cervical ribs, shown in green. F, G. Muscles inserting on the neural spine, shown in blue. H. Muscles inserting on the ansa costotransversaria (“cervical rib loop”), shown in brown. Specifically: A. M. longus colli dorsalis. B. M. cervicalis ascendens. C. M. flexor colli lateralis. D. M. flexor colli medialis. E. M. longus colli ventralis. In birds, this muscle originates from the processes carotici, which are absent in the vertebrae of sauropods. F. Mm. intercristales. G. Mm. interspinales. H. Mm. intertransversarii. Vertebrae modified from Gilmore (1936, plate 24).

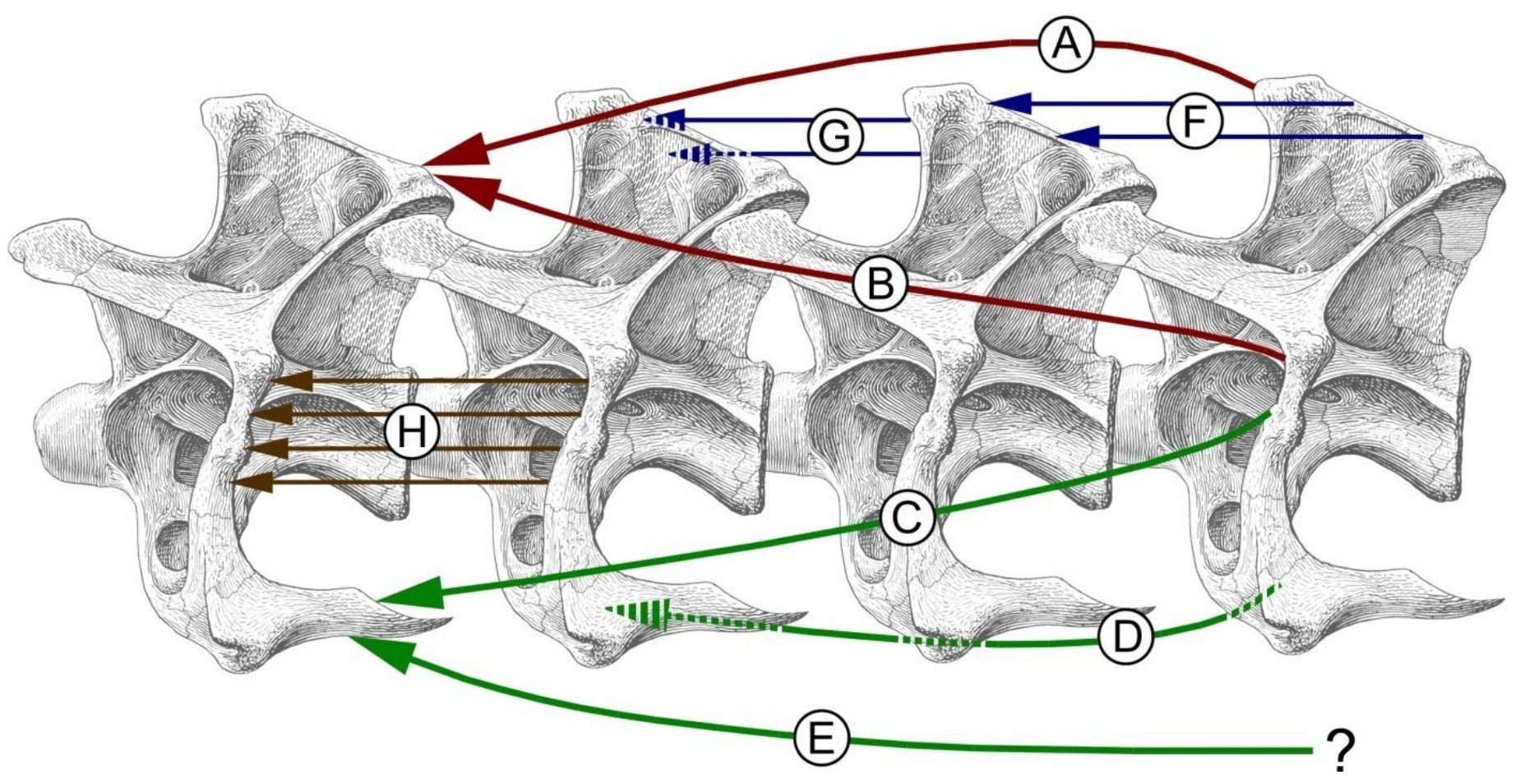




\section{Figure 6}

Basic cervical vertebral architecture in archosaurs.

Basic cervical vertebral architecture in archosaurs, in posterior and lateral views. 1, seventh cervical vertebra of a turkey, Meleagris gallopavo Linnaeus 1758, traced from photographs by MPT. 2, fifth cervical vertebra of the abelisaurid theropod Majungasaurus crenatissimus Depéret 1896, UA 8678, traced from O'Connor (2007, figures 8 and 20). In these taxa, the epipophyses and cervical ribs are aligned with the expected vectors of muscular forces. The epipophyses are both larger and taller than the neural spine, as expected based on their mechanical importance. The posterior surface of the neurapophysis is covered by a large rugosity, which is interpreted as an interspinous ligament scar like that of birds (O'Connor 2007). Because this scar covers the entire posterior surface of the neurapophysis, it leaves little room for muscle attachments to the spine. 3, fifth cervical vertebra of Alligator mississippiensis Daudin 1801, MCZ 81457, traced from 3D scans by Leon Claessens, courtesy of MCZ. Epipophyses are absent. 4, eighth cervical vertebra of Giraffatitan brancai (Janensch 1914) paralectotype HMN SII, traced from Janensch (1950, figures 43 and 46). Abbreviations: cr, cervical rib; e, epipophysis; ns, neural spine; poz, postzygapophysis.

1

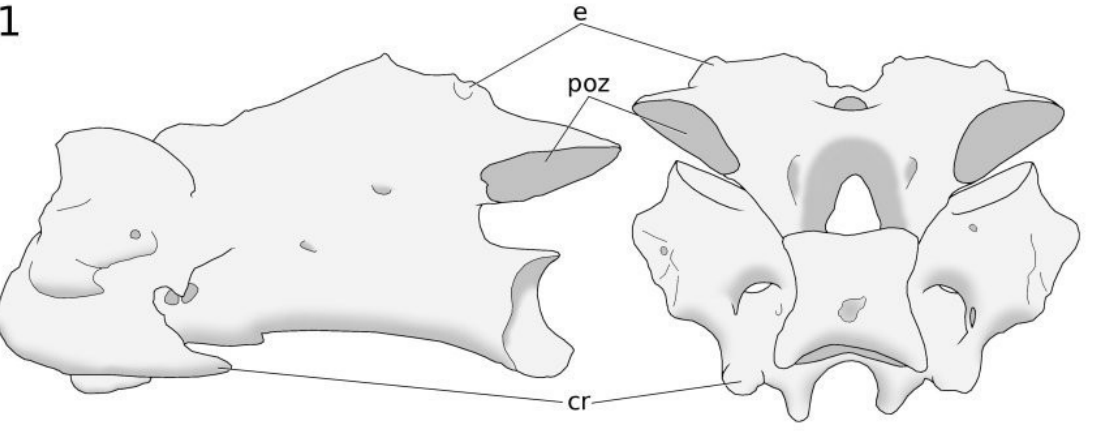

2

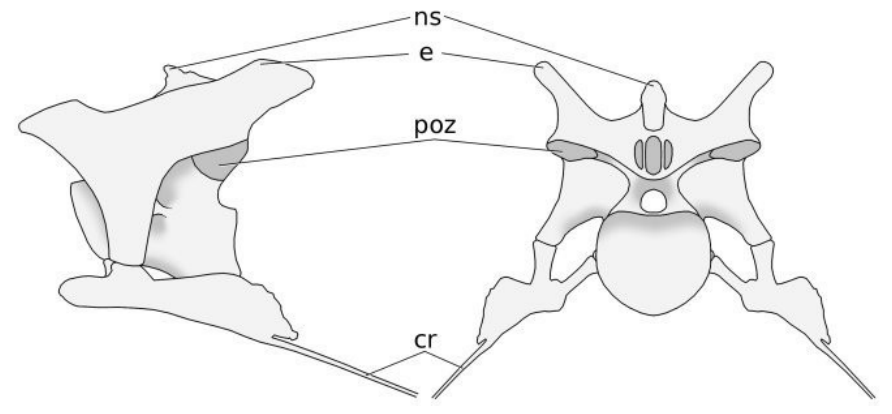

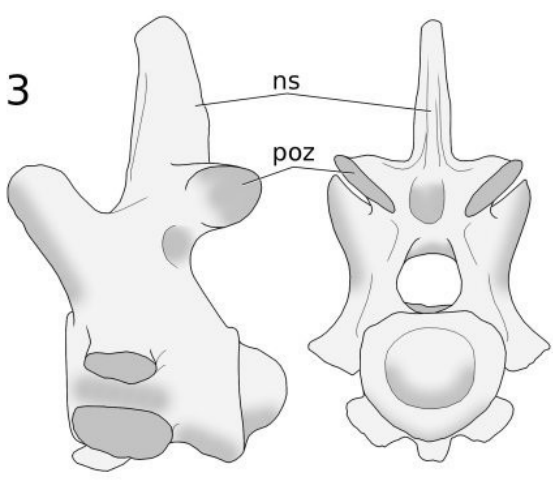

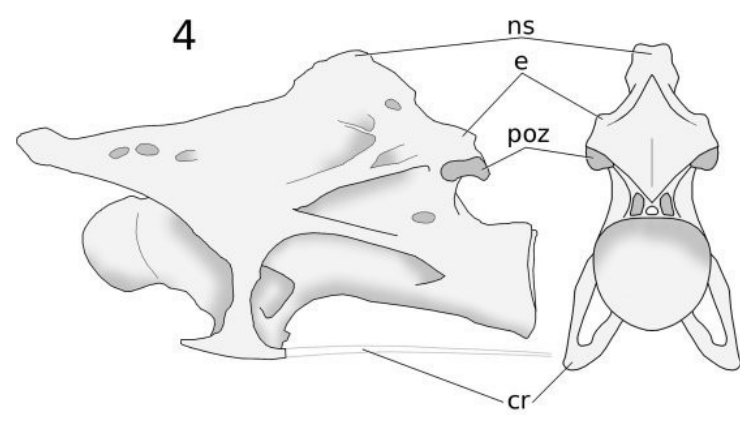




\section{Figure 7}

Disparity of sauropod cervical vertebrae.

Disparity of sauropod cervical vertebrae. 1, Apatosaurus “laticollis” Marsh 1879b holotype YPM 1861, cervical ?13, now referred to Apatosaurus ajax (see McIntosh 1995), in posterior and left lateral views, after Ostrom and McIntosh (1966, plate 15); the portion reconstructed in plaster (Barbour 1890, figure 1) is grayed out in posterior view; lateral view reconstructed after Apatosaurus louisae Gilmore 1936 (Gilmore 1936, plate XXIV). 2, “Brontosaurus excelsus” Marsh 1879a holotype YPM 1980, cervical 8, now referred to Apatosaurus excelsus (see Riggs 1903), in anterior and left lateral views, after Ostrom and McIntosh (1966, plate 12); lateral view reconstructed after Apatosaurus louisae (Gilmore 1936, plate XXIV). 3, “Titanosaurus” colberti Jain and Bandyopadhyay 1997 holotype ISIR 335/2, mid-cervical vertebra, now referred to Isisaurus (See Wilson and Upchurch 2003), in posterior and left lateral views, after Jain and Bandyopadhyay (1997, figure 4). 4, “Brachiosaurus” brancai paralectotype HMN SII, cervical 8, now referred to Giraffatitan (see Taylor 2009), in posterior and left lateral views, modified from Janensch (1950, figures 43-46). 5, Erketu ellisoni holotype IGM 100/1803, cervical 4 in anterior and left lateral views, modified from Ksepka and Norell (2006, figures 5a-d). 


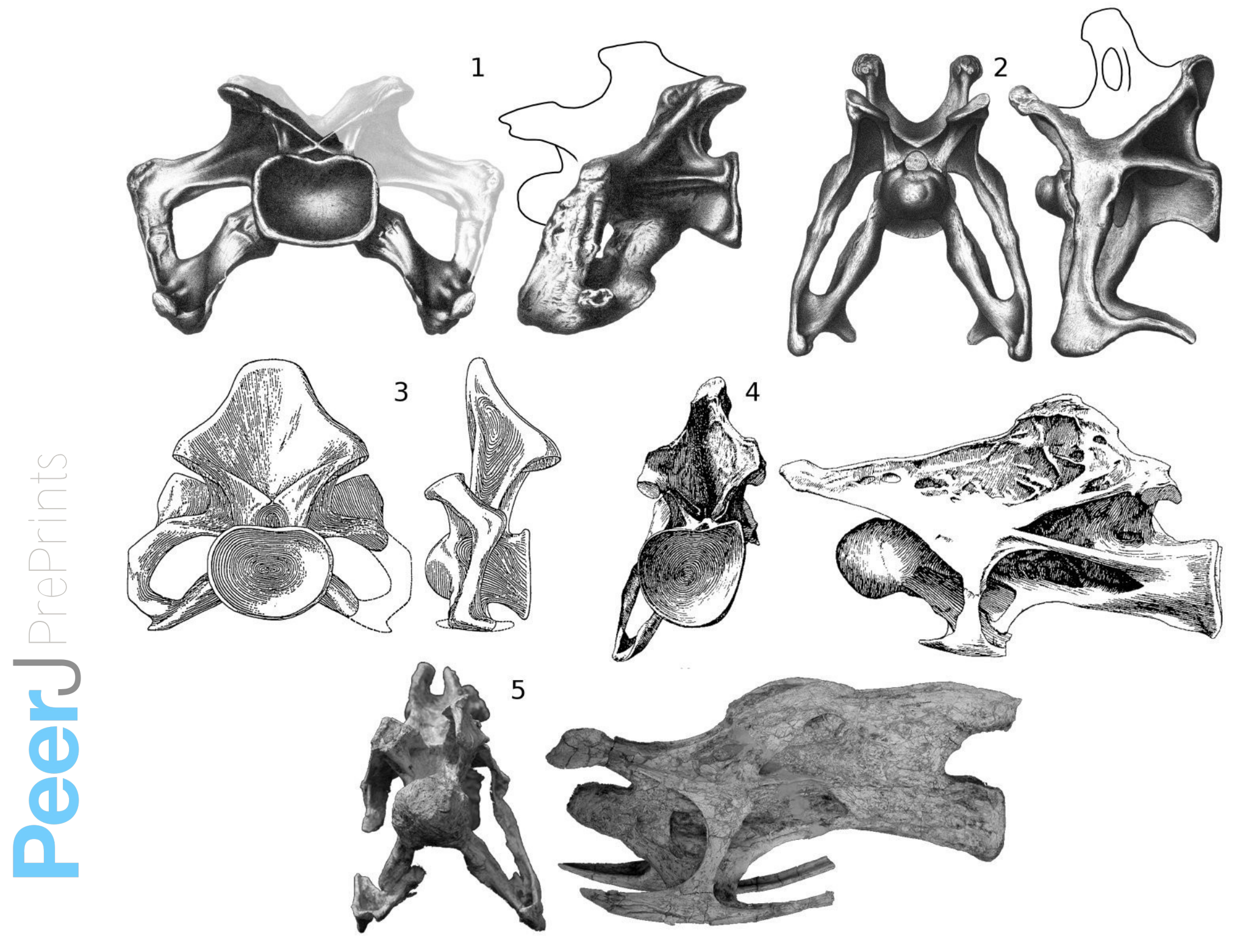




\section{Figure 8}

Sauropod cervical vertebrae showing anteriorly and posteriorly directed spurs projecting from neurapophyses.

Sauropod cervical vertebrae showing anteriorly and posteriorly directed spurs projecting from neurapophyses. 1, cervical 5 of Sauroposeidon holotype OMNH 53062 in right lateral view, photograph by MJW. 2, cervical 9 of Mamenchisaurus hochuanensis holotype CCG V 20401 in left lateral view, reversed, from photograph by MPT. 3, cervical 7 or 8 of Omeisaurus junghsiensis Young 1939 holotype in right lateral view, after Young (1939, figure 2). (No specimen number was assigned to this material, which has since been lost. D. W. E. Hone personal communication 2008.)

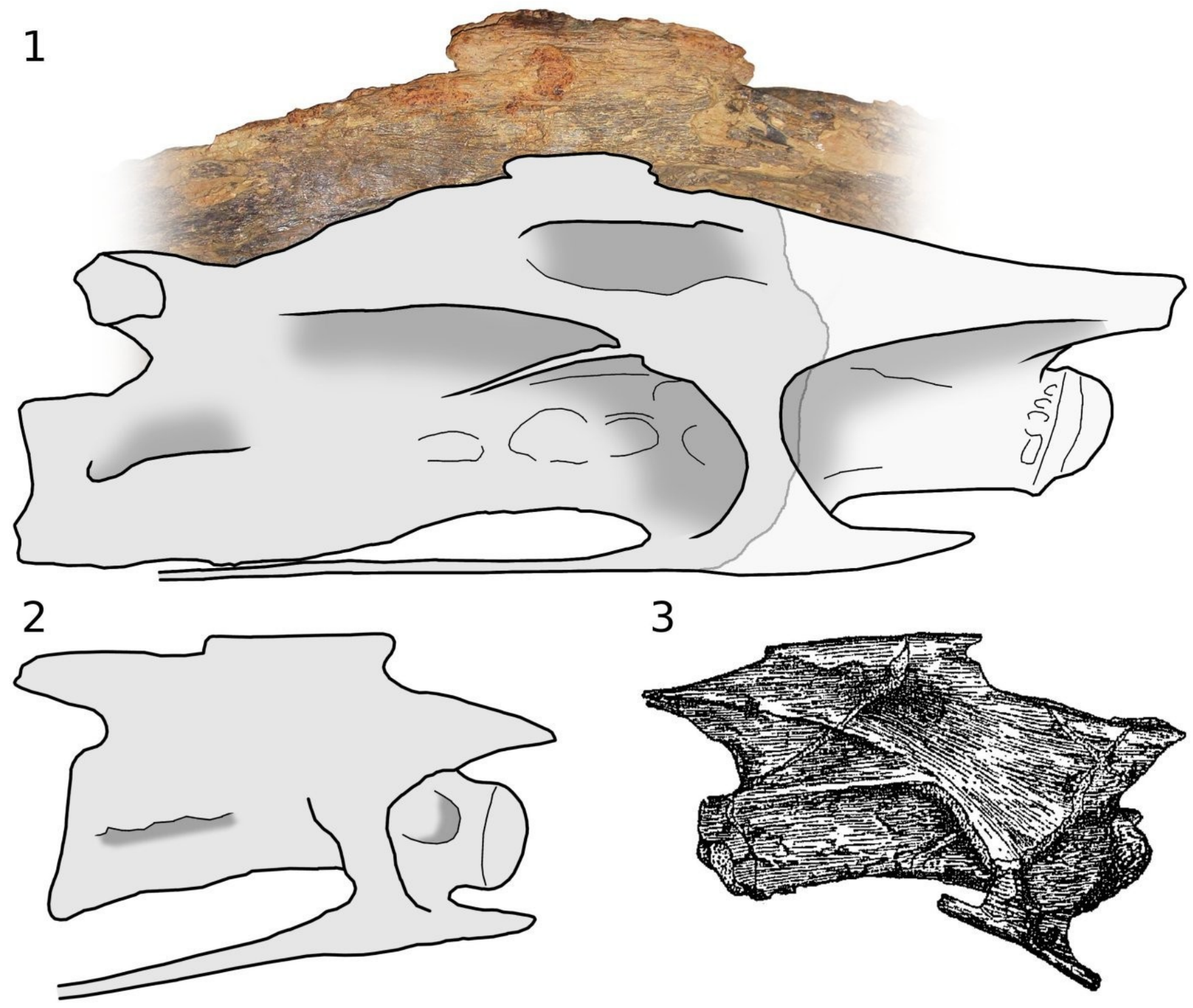




\section{Figure 9}

Ligament scars and pneumatic foramina in intermetapophyseal troughs.

Bifid presacral vertebrae of sauropods showing ligament scars and pneumatic foramina in the intermetapophyseal trough. 1, Apatosaurus sp. cervical vertebra OMNH 01341 in right posterodorsolateral view, photograph by MJW. 2, Camarasaurus sp. dorsal vertebrae CM 584 in dorsal view, photograph by MJW. Abbreviations: las, ligament attachment site; pfa, pneumatic fossa; pfo, pneumatic foramen. 


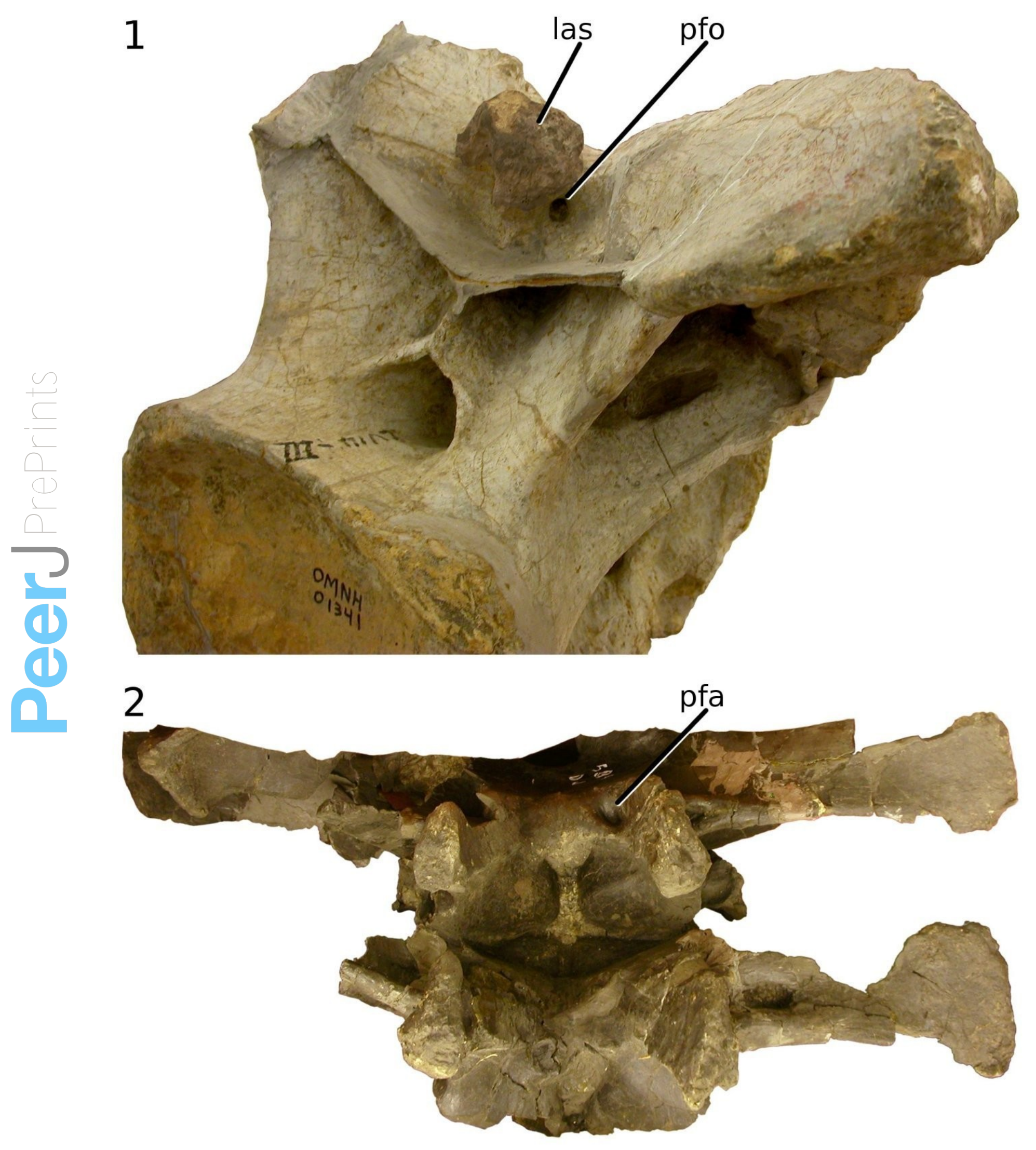




\section{Figure 10}

Real and speculative muscle attachments in sauropod cervical vertebrae.

Real and speculative muscle attachments in sauropod cervical vertebrae. 1, the second through seventeenth cervical vertebrae of Euhelopus zdanskyi Wiman 1929 cotype specimen PMU R233a- $\delta$ ("Exemplar a"). 2, cervical 14 as it actually exists, with prominent but very short epipophyses and long cervical ribs. 3, cervical 14 as it would appear with short cervical ribs. The long ventral neck muscles would have to attach close to the centrum. 4, speculative version of cervical 14 with the epipophyses extended posteriorly as long bony processes. Such processes would allow the bulk of both the dorsal and ventral neck muscles to be located more posteriorly in the neck, but they are not present in any known sauropod or other non-avian dinosaur. Modified from Wiman (1929, plate 3).

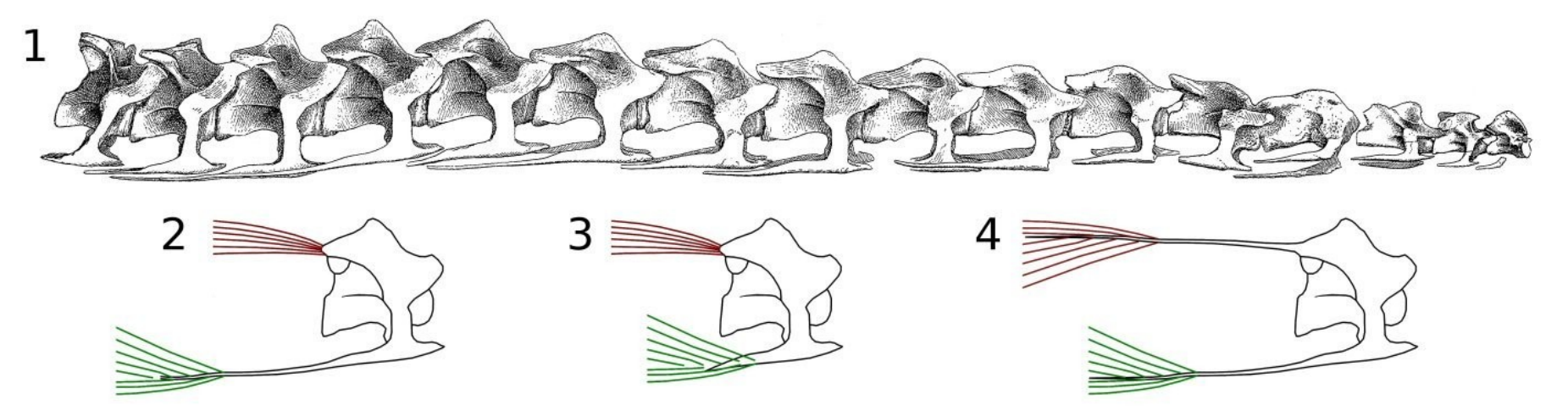




\section{Figure 11}

Archosaur cervical vertebrae in posterior view, Showing muscle attachment points in phylogenetic context.

Archosaur cervical vertebrae in posterior view, Showing muscle attachment points in phylogenetic context. Blue arrows indicate epaxial muscles attaching to neural spines, red arrows indicate epaxial muscles attaching to epipophyses, and green arrows indicate hypaxial muscles attaching to cervical ribs. While hypaxial musculature anchors consistently on the cervical ribs, the principle epaxial muscle migrate from the neural spine in crocodilians to the epipophyses in non-avial theropods and modern birds, with either or both sets of muscles being significant in sauropods. 1, fifth cervical vertebra of Alligator mississippiensis, MCZ 81457, traced from 3D scans by Leon Claessens, courtesy of MCZ. Epipophyses are absent. 2, eighth cervical vertebra of Giraffatitan brancai paralectotype HMN SII, traced from Janensch (1950, figures 43 and 46). 3, eleventh cervical vertebra of Camarasaurus supremus, reconstruction within AMNH 5761/X, “cervical series I”, modified from Osborn and Mook (1921, plate LXVII). 4, fifth cervical vertebra of the abelisaurid theropod Majungasaurus crenatissimus, UA 8678, traced from O'Connor (2007, figures 8 and 20). 5, seventh cervical vertebra of a turkey, Meleagris gallopavo, traced from photographs by MPT.

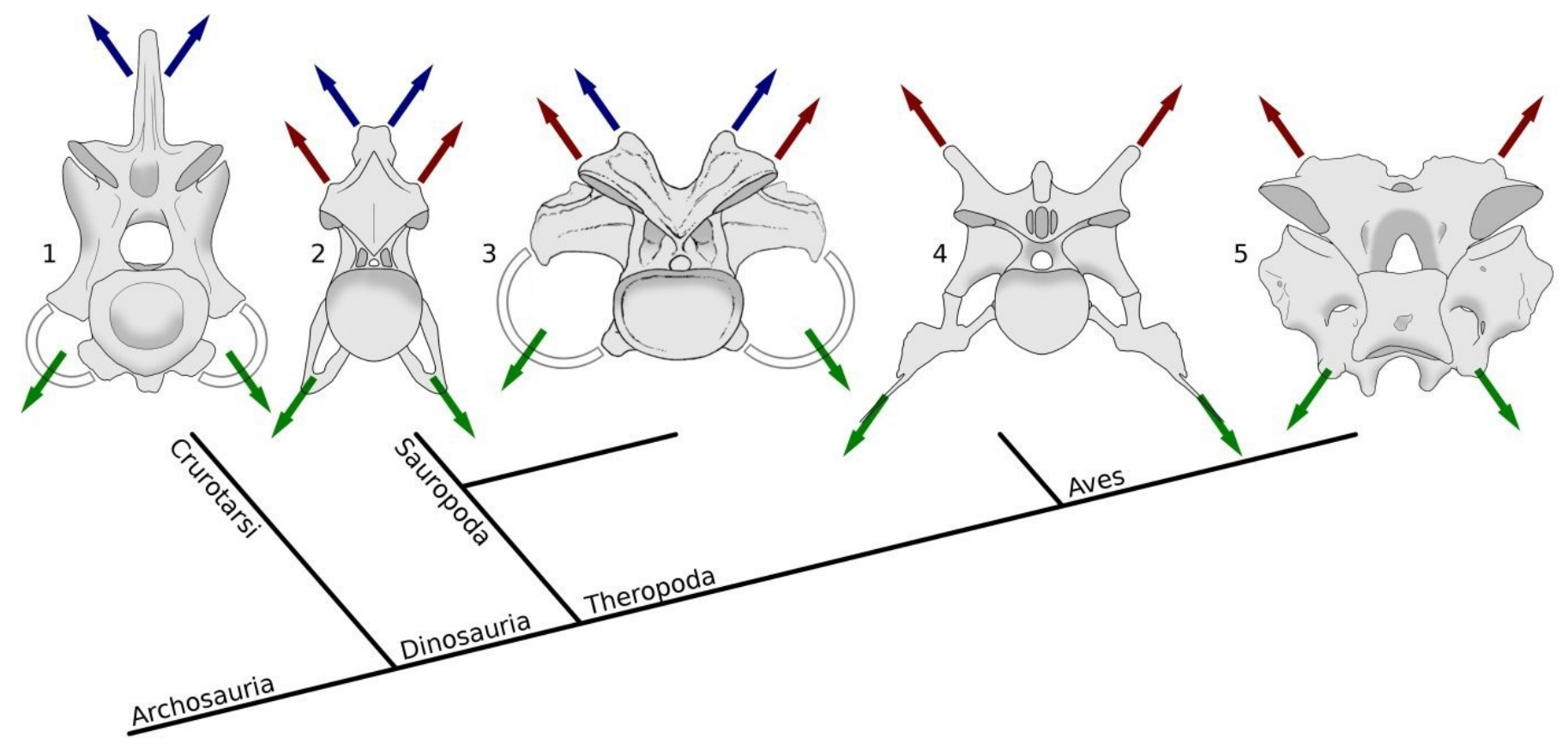

